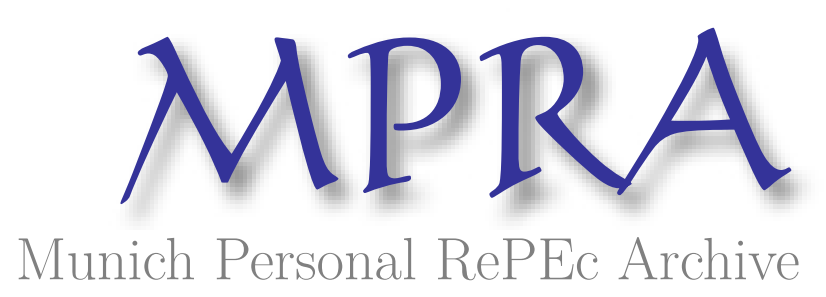

\title{
Fed Policy Expectations and Portfolio Flows to Emerging Markets
}

Koepke, Robin

Institute of International Finance, University of Wurzburg

25 May 2014

Online at https://mpra.ub.uni-muenchen.de/63519/

MPRA Paper No. 63519, posted 11 Apr 2015 10:04 UTC 


\title{
Fed Policy Expectations and Portfolio Flows to Emerging Markets
}

\author{
Robin Koepke ${ }^{1}$
}

This version: April 2015

\begin{abstract}
The empirical literature has long established that U.S. interest rates are an important driver of international portfolio flows, with lower rates "pushing" capital to emerging markets. On the basis of this literature, it is often argued that the Federal Reserve's imminent policy tightening cycle is likely to weigh on portfolio flows to emerging markets in coming years. The analysis presented in this paper offers a different interpretation of the literature, suggesting that it is the surprise element of monetary policy that affects EM portfolio inflows. A shift in market expectations towards easier future U.S. monetary policy leads to greater foreign portfolio inflows and vice versa. Given current market expectations of sustained increases in the federal funds rate in coming years, EM portfolio flows could be boosted by a slower pace of Fed tightening than currently expected or could be reduced by a faster pace of Fed tightening.
\end{abstract}

JEL Classification Numbers: E43, F32, F41, F42, G11

Keywords: Capital Flows, Emerging Markets, Monetary Policy, Market Expectations, Push and Pull

\footnotetext{
${ }^{1}$ Institute of International Finance and University of Wurzburg. 1333 H St NW, Suite 800E, Washington, DC 20005. Email: rkoepke@iif.com. I am grateful for helpful comments and suggestions by Peter Bofinger, Guillermo Calvo, Charles Collyns, Marcel Fratzscher, Marc Hinterschweiger, Felix Huefner, Jeremy Lawson, Laura Piscitelli, and participants at an IMF Capital Flows Group seminar.
} 


\section{Introduction}

Will capital flows to emerging markets wane during the Fed's imminent policy tightening cycle? The existing empirical literature seems to suggest that flows should indeed weaken as the Fed raises policy rates. Many studies have found that U.S. interest rates are a key driver of capital flows to EMs (e.g., Fernandez-Arias 1996; Taylor and Sarno 1997; Baek 2006; De Vita and Kyaw 2008; Bluedorn et al. 2013). The common interpretation of the existing empirical findings is that low U.S. interest rates tend to "push" capital to EMs, while higher interest rates reduce those flows. An early example of this reasoning is the seminal study by Fernandez-Arias $(1996,414)$, who concludes that "[c]apital inflows in the typical country are largely dependent on favorable international interest rates and, ceteris paribus, would not be sustained if they return to higher levels." The analysis presented in this paper suggests otherwise. This paper argues that the literature has omitted an important aspect when examining the role of foreign interest rates in driving capital flows, namely the role of market expectations. It is argued that one should expect an adverse impact on capital flows primarily, if not exclusively, if interest rates rise faster than previously expected. In recent years, futures markets have consistently anticipated significant and sustained increases in both the short-term policy interest rate and long-term market interest rates for the years ahead. If rates were to increase less rapidly than priced in by markets, this could instead boost EM portfolio flows. This expectations perspective yields a rather different and more nuanced assessment of the risks and opportunities of the imminent Fed rate hike cycle than the prevailing wisdom suggests. The focus on the unanticipated component of interest rate increases is the first contribution of this paper.

The second contribution relates specifically to the role of expectations for Fed policy in driving portfolio flows. The empirical analysis presented in this study suggests that the surprise element of interest rate movements is closely linked to monetary policy shocks. Federal funds futures contracts help identify those surprises and make it possible to quantify the extent to which a shift in the expected rate path typically impacts capital flows. The empirical analysis is thus in the spirit of Hamilton $(2008,1171)$, who emphasizes that the primary source of monetary policy shocks "is not what the Fed just did, but is instead new information about the Fed's future intentions." This paper applies this perspective to the EM capital flows literature and argues that when market participants come to expect a more expansionary Fed monetary policy, investors allocate more capital to emerging markets and vice versa. This is the first study that links capital flows movements to changes in monetary policy expectations. ${ }^{2}$ This link allows policymakers and investors to use information from federal funds futures contracts as a planning tool for policy analysis and risk management by

\footnotetext{
${ }^{2}$ I presented preliminary estimation results in IIF (2013) and Koepke (2013).
} 
considering alternative scenarios for the future path of the federal funds rate. For example, in IIF (2014) I model a risk scenario in which Fed interest rate hikes are implemented at the same pace as during the 2004-2006 tightening cycle, rather than at the much slower pace that futures markets have anticipated in recent years. Based on financial conditions prevailing in mid-2014, such a scenario would result in a substantial upward shift in the path of expected future policy rates, likely triggering a sharp reduction in non-resident portfolio flows to emerging markets that could have considerable effects on asset prices and economic activity.

The third contribution of this paper is to help bridge the gap between high-frequency data on fund flows and international portfolio flows as measured in the balance of payments (BoP). Fund flows data such as the data by EPFR Global have become increasingly popular in the academic and policy literature in recent years (e.g., Fratzscher 2012; Lo Duca 2012; Ananchotikul and Zhang 2014). While fund flows are certainly of significant scholarly interest on their own merits, they are conceptually different from international portfolio flows in a number of ways and are subject to various sampling issues (see Section 4). It is thus no surprise that the two data sources differ significantly in their magnitude and dynamic behavior. Arguably, empirical studies have not been emphatic enough in pointing out the differences between fund flows and international portfolio flows as defined in the BoP (Koepke 2015). To my knowledge, this paper is the first to provide estimation results on the determinants of portfolio flows using both EPFR fund flows data and BoP-consistent portfolio flows data. For the latter, I use a novel data set on monthly portfolio flows that is compiled based on national sources of 14 EM countries and is regularly updated by the Institute of International Finance (IIF). ${ }^{3}$ The core findings of this study are shown to hold for both data sources, despite their many differences.

In terms of the estimation results, two main findings stand out: First, changes in U.S. monetary policy expectations have a statistically significant and economically important impact on both EM fund flows and BoP-consistent portfolio flows. A one percentage point shift in market expectations for the federal funds rate three years forward is estimated to reduce portfolio flows by about $\$ 15$ billion contemporaneously. For fund flows, the estimated impact is smaller in the short term (-\$11.5 billion), but larger in the long-term (-\$21 billion).

In addition, in the current U.S. business cycle, shifts in expectations towards tighter monetary policy have tended to exert a greater impact on EM portfolio inflows than shifts towards easier monetary policy. For fund flows, the estimated coefficient is about 2-2.5 times as large for months when

${ }^{3}$ The dataset is posted on the following website: https://www.iif.com/publications/portfolio-flows-tracker. Aggregate data are publicly available while country-level data are restricted to IIF members. 
expected policy rates went up compared to months when they went down. For portfolio flows, the factor is even larger. A disaggregation of the fund flows dataset by investor type suggests that the asymmetric response to upward shifts in Fed policy rate expectations is driven primarily by retail investors, rather than institutional investors.

The model setup also makes it possible to test a number of additional hypotheses. For example, it enables an assessment of how the Fed's large-scale asset purchases have impacted flows to emerging markets. There is some evidence that changes in the pace of asset purchases have had an impact on EM fund flows above and beyond what is captured by the market expectations channel. The long-term impact of a one-time $\$ 10$ billion reduction in the pace of Fed asset purchases is estimated to be a reduction in EM fund flows by a total of $\$ 2$ billion.

In addition, I find tentative evidence for a market expectations channel relating to country-level developments: An economic surprise index that captures the strength of the economic data flow in emerging economies relative to market expectations is a statistically significant explanatory variable for portfolio equity flows, at least in the post-crisis period.

Another finding relates to the role of policy interest rate differentials between emerging and advanced economies, which are often seen as an important driver of portfolio flows in the context of the carry trade (see for example Galati et al. 2007). This variable is tested as a potential explanatory variable in a variety of model specifications, which do not yield statistically robust evidence that policy interest rate differentials were a driver of portfolio flows in either the pre-crisis or the postcrisis period.

The rest of this paper is organized as follows: Section 2 reviews the literature. Section 3 provides the conceptual framework for the role of monetary policy in driving portfolio flows to EM economies. Section 4 describes the data used in the empirical part and presents the empirical methodology. Section 5 discusses the detailed estimation results and Section 6 provides a range of robustness checks. Section 7 concludes.

\section{Literature Overview}

The voluminous literature on the drivers of capital flows to emerging markets has firmly established the importance of both country-specific "pull" factors and global "push" factors. Pull factors primarily relate to economic growth, country risk factors and return prospects in emerging market 
countries. By contrast, push factors affect the supply of foreign capital and relate to global financial conditions, most notably the global interest rate environment and investor risk appetite.

The focus of this paper is primarily on the role of U.S. interest rates, a push factor. The important role of U.S. interest rates and other external factors was first identified in the seminal paper by Calvo, Leiderman and Reinhart (1993). Using principal component analysis, the authors find that record-low U.S. interest rates after the 1990/1991 recession had contributed to the rebound in capital flows to Latin American economies. The authors argued that capital flows could slow or even reverse once U.S. interest rates would reach more normal levels. Most subsequent studies find further support for the role of U.S. interest rates. Fernandez-Arias (1996) argues that a lower level of U.S. interest rates can temporarily improve a country's creditworthiness by lowering its borrowing costs, helping it to attract additional foreign capital. Taylor and Sarno (1997) find U.S. interest rates to be particularly important in driving short-term portfolio flows to EM economies, especially for bond flows. Baek (2006) argues that while low returns on "riskless" U.S. Treasury securities boost portfolio investment in emerging markets, low returns on riskier global equity markets have the opposite impact.

Bluedorn et al. (2013) find that both non-resident capital inflows to emerging markets and resident capital outflows increase when interest rates in advanced economies are low.

A few studies do not find evidence that U.S. interest rates are driving EM capital flows. For example, Hernandez et al. (2001) conclude that the real international interest rate is not a significant driver of EM capital flows at the annual frequency, when controlling for domestic factors. This may suggest that the impact of changes interest rates plays out over a relatively short time period, such that the effect may not be detected at low data frequencies. This explanation would be consistent with the notion that it is the surprise element of interest rate changes that matters for capital flows (since short-term U.S. interest rate movements are typically almost entirely unexpected while long-term interest rate movements can have a significant anticipated component - see next section). As a further caveat, Forbes and Warnock (2011) find that global interest rates do not seem to be a significant factor during extreme capital flows episodes such as surges and reversals of flows to an EM economy.

In terms of the variable specification for U.S. interest rates, most studies use some form of marketbased yield on U.S. Treasury securities to proxy U.S. and global interest rate conditions (but do not make use of Fed policy variables per se). ${ }^{4}$ Frequently used maturities include the 3 - and 12 -month

\footnotetext{
${ }^{4}$ One exception is the above-mentioned paper by Ahmed and Zlate (2013), which uses the policy interest rate differential between the U.S. and emerging economies as an explanatory variable. Another exception is Bruno and Shin (2015), who focus on the banking sector and find that an increase in the federal funds rate reduces cross-border bank credit flows.
} 
T-bill rates and the 10-year Treasury yield (e.g., Fernandez-Arias 1996; World Bank 1997; Montiel and Reinhart 1999; De Vita and Kyaw 2008). A few studies use the LIBOR rate instead, which also captures stress in the interbank market (e.g., Gupta and Ratha 2000; Hernandez et al. 2001). A limited number of studies uses U.S. short-term policy interest rates, i.e. the federal funds target or effective rates (e.g., Ahmed and Zlate 2013; Bruno and Shin 2015). It is also noteworthy that most studies use nominal interest rates, although a few deflate nominal interest rates by a measure of U.S. inflation, generally the headline consumer price index (e.g., Hernandez et al. 2001; Jeanneau and Micu, 2002).

While most of the empirical literature analyzes U.S. or global interest rates as self-standing drivers of capital flows, some have looked at the interest rate differentials between emerging and advanced economies. For example, Ahmed and Zlate (2013) find that a wider policy interest rate differential in favor of emerging markets tends to boost capital flows (including portfolio flows), and that this effect has increased after the global financial crisis. However, their robustness checks also indicate different effects of emerging and mature economy interest rates on capital flows in terms of magnitude and statistical significance. Herrmann and Mihaljek (2013) investigate whether interest rate differentials affect banking flows to emerging markets and find supporting evidence for some emerging market regions (Asia and Latin America), but not others (central and eastern Europe). A recent study by the World Bank (2014) does not find statistically robust evidence in support of interest rate differentials.

Recent research on the Fed's impact on EM capital flows has focused on the Fed's unconventional monetary policies, especially its asset purchase programs. Fratzscher et al. (2012) find a significant impact of Fed asset purchases on portfolio flows and asset prices using weekly data on flows to EMdedicated funds from EPFR. Ahmed and Zlate (2013) analyze quarterly balance of payments data on capital flows and find that unconventional U.S. monetary policy has shifted the composition of capital inflows towards portfolio investments while leaving the volume of flows unaffected. A more recent study by the World Bank (2014) concludes that the Fed's three asset purchase programs have had a significant, but diminishing impact on the volume of EM capital flows over time.

Aside from interest rates in mature economies, a second important push factor is global risk aversion. In particular, since the global financial crisis of 2008/2009, many studies have emphasized the importance of investor risk appetite as a driving factor for capital flows, and have generally proxied this factor with the U.S. equity volatility index (VIX) or the U.S. BBB-rated corporate bond spread over Treasuries (Fratzscher 2012; Forbes and Warnock 2011; Bruno and Shin 2015; Lo Duca 2012; Ahmed and Zlate 2013; Bluedorn et al. 2013; Rey 2013). For example, Milesi-Ferretti and Tille 
(2011) interpret the global crisis as an intense shock to global risk aversion that had severe ripple effects for emerging market economies.

In terms of pull factors, the single most important determinant identified in the literature is domestic real GDP growth (Gupta and Ratha 2000; Hernandez 2001; Ferucci et al. 2004; De Vita and Kyaw 2008, Bruno and Shin 2015). Higher output growth boosts corporate profitability, increasing the returns on equity investments. Strong growth also benefits returns on fixed income investments by improving borrowers' ability to service debt, be it via stronger earnings for corporate borrowers or greater tax revenues and lower public spending needs for sovereign borrowers. Country risk indicators constitute another important set of pull factors. These indicators include the ratio of external debt to GDP (Jeanneau and Micu 2002; Ferucci et al. 2004), the ratio of public debt to GDP (Forbes and Warnock 2011; Fratzscher 2012), the level of development as proxied by GDP per capita (World Bank 1997; Gupta and Ratha 2000; Forbes and Warnock 2011; Milesi-Ferretti and Tille 2011) and measures of institutional quality, which are particularly important for FDI inflows because these are generally long term in nature (Ahlquist 2006; Fratzscher 2012). A third set of pull factors includes asset return indicators such as the local equity market return (Chuhan et al. 1998; Ferucci et al. 2004; Montiel and Reinhart 1999; Lo Duca 2012) and emerging market exchange rates or FX volatility (Hernandez 2001; Jeanneau and Micu 2002; Ferucci et al. 2004; Baek 2006).

This study also builds on the literature about the relationship between Fed policy actions and U.S. market interest rates, which was first addressed in the seminal work by Cook and Hahn (1989). In an event study approach, the authors estimate the impact of changes in the federal funds target rate on bond yields during the 1970s, and find a significant and positive effect across maturities. Subsequent studies found a smaller impact for later sample periods, however (e.g., Roley and Sellon 1995). Kuttner (2001) provides an explanation for the diminishing impact of changes in the federal funds target rate on bond yields, arguing that market participants had become better at predicting imminent policy rate changes, mainly because Fed policy had become more transparent over time. His analysis distinguishes between anticipated and unanticipated changes in the federal funds rate, which shows that it is the unanticipated component of Fed actions that affects market interest rates, while anticipated changes have virtually no effect on market interest rates. Hamilton (2008), develops this point further by emphasizing that monetary policy shocks are primarily about news regarding what the Fed is going to do in the future rather than its most recent actions. In other words, the impact of monetary policy on the economy is thought to arise from changes in the entire path of future short-term interest rates anticipated by markets. Gürkaynak (2005) provides a useful framework for analyzing these changes by decomposing shifts in the fed funds futures path into timing, level, and slope components. His analysis also shows that asset prices are most affected by 
shifts in the futures curve that extend beyond the near term (i.e. a level shift in the futures path or a change in its slope, rather than a mere change in the timing of a near-term change in the fed funds target rate).

The next section sets out the analytical framework for the relationship between monetary policy expectations and U.S. market interest rates in the context of the literature on the drivers of EM capital flows.

\section{Conceptual Framework for the Role of Monetary Policy Expectations}

The focus of this paper is to explore the link between U.S. monetary policy and EM capital flows. In order to frame the monetary policy expectations approach taken in this study in the context of the existing literature, it is helpful to review the theoretical link between monetary policy expectations and market interest rate variables used in much of the literature. According to the expectation theory of the term structure of interest rates, the forces affecting Treasury yields can be broken down into two components, namely the expected path of future short-term interest rates and the term premium (Kim and Wright 2005). The first component reflects market expectations of how the Fed will set the policy interest rate over time. If market participants come to expect tighter U.S. monetary policy in the future, yields on Treasury securities will go up (other things equal).

The term premium captures the additional yield required by investors to hold a bond with a longer maturity rather than holding a series of short-term bonds. Changes in the term premium reflect shifts in the demand and supply of Treasury securities, which may occur for many reasons. Accordingly, a change in market expectations for Fed policy will generally have an immediate impact on Treasury yields, reflecting a revised path of expected future short-term interest rates. ${ }^{5}$ At the same time, Treasury yields can fluctuate due to a host of factors unrelated to changes in the expected path of future short-term interest rates, to the extent that these factors impact the term premium. Therefore, using federal funds futures contracts as an explanatory variable for capital flows movements can be considered a more targeted approach than using overall market interest rates.

While most empirical studies have made use of market interest rates, some studies have instead used U.S. monetary policy variables, such as the federal funds target rate or effective rates (e.g.,

\footnotetext{
${ }^{5}$ Note that U.S. monetary policy affects a host of other financial variables besides Treasury yields, such as yields on corporate bonds and mortgage backed securities, as well as also stock prices and exchange rates.
} 
Ahmed and Zlate 2013; Bruno and Shin 2015). This approach is complicated by a number of factors, however. First, U.S. policy interest rates are often stable for extended periods, making it difficult to model them empirically. This is particularly noteworthy for the period following the global financial crisis, after which the federal funds target rate has been unchanged at 0-0.25 percent for over six years (since December 2008).

Another issue is that monetary policy works via the expectations channel, as emphasized in the recent literature (Kuttner 2001; Hamilton 2008). Market participants act in anticipation of changes in monetary policy settings, meaning that financial asset prices will quickly incorporate new information about the future course of monetary policy (for recent estimates of the impact of monetary policy shocks on stock markets, see Bernanke and Kuttner 2005). Given the immediate adjustment of asset prices to a shift in market expectations of monetary policy, it is plausible that such shifts also trigger reallocations of investor portfolios even in the absence of a change in the monetary policy settings. The fact that the literature has generally relied on changes in market interest rates (which capture both anticipated and unanticipated movements in interest rates) rather than changes in policy interest rates (which are often fully anticipated) may be may be an indication that it is indeed the unanticipated element of interest rate movements that matters for international capital flows.

In this context, it is noteworthy that the relative magnitude of expected vs. unexpected changes in interest rates varies for different data frequencies. Anticipated interest rate increases are quite small at short time horizons (for example, in recent years, futures markets have typically priced in increases in 10-year Treasury yields in the range of two to four basis points per month), while short-term fluctuations in current market interest rates can be sizeable. Over longer time horizons, anticipated interest rate changes are typically much larger since the anticipated monthly interest rate changes essentially accumulate (i.e. expected monthly changes typically all have the same sign), while much of the unanticipated monthly fluctuations in interest rates cancel out. Consistent with this, the existing literature has typically found that changes in interest rates are an important driver of EM capital flows at high frequencies (e.g., Taylor and Sarno 1997; Fratzscher et al. 2012, Feroli et al. 2014), but not at low frequencies (e.g., Hernandez et al. 2001). Though prior work has not distinguished between anticipated and unanticipated interest rate increases, these findings seem to provide support for the notion that anticipated interest rate increases do not have a statistically significant impact on EM portfolio flows.

The approach taken in this paper is to take account of the forward-looking nature of interest rate markets and monetary policy by focusing on the unanticipated component of changes in interest 
rates. Specifically, I make use of federal fund futures contracts to measure the extent to which future changes in policy interest rates are priced in by financial markets. Changes in the future interest rates implied by federal funds futures contracts indicate a revised path for monetary policy, capturing the unanticipated component of changes in interest rates. The main hypothesis is that these changes in Fed policy rat expectations drive international portfolio flows movements, with shifts towards easier anticipated future monetary policy resulting in a boost to portfolio flows to emerging markets, and vice versa.

\section{Data and Empirical Strategy}

I use two alternative datasets on portfolio flows to emerging markets. The first is data from Emerging Portfolio Fund Research (EPFR) Global on equity and bond flows into EM-dedicated funds, which are commonly used as a high-frequency proxy for non-resident (or "gross") portfolio flows to emerging markets (see Miao and Pant 2012). Equity fund flows are available from February 1996 onwards and bond flows are available starting in November 2003. The data are based on a large sample of mutual funds and exchange-traded funds (ETFs) whose fund managers/administrators report to EPFR Global. As of late March 2014, the EM equity flows data were based on funds with a total of $\$ 1,027$ billion of assets under management, while the corresponding bond funds have $\$ 320$ billion under management. In addition to the aggregated movements in and out of funds, EPFR makes available disaggregated data on the basis of investor type (institutional vs. retail), domicile (by country), and currency, among others. EPFR fund flows data have enjoyed growing popularity in the academic literature in recent years (e.g., Fratzscher 2012, Lo Duca 2012, Ananchotikul and Zhang 2014). In addition, EPFR data are widely relied on in the financial industry as a timely high-frequency indicator of portfolio flows movements.

Despite their growing popularity, there are a number of caveats regarding the use of fund flows data (see Brandt et al. 2015). Conceptually, transactions captured by fund flows are not necessarily capital flows because the transactions may not be between the residents of an emerging market country and non-residents. This is because investment funds and the counterparties to their transactions may be residents of any country in the world. In addition, funds maintain cash buffers, meaning that an inflow to a fund does not necessarily prompt the fund to purchase a security. Moreover, EPFR fund flows data do not treat dividend distributions in the same way as under standard BoP practices (International Monetary Fund 2010; Emerging Portfolio Fund Research Global 2015). Reinvested dividends are recorded as an inflow in the BoP accounting framework, but do not affect fund flows estimates. Conversely, cash dividend payments are recorded as an outflow in the fund flows data, 
but not in BoP data. This difference is likely to account for some of the downward bias in fund flows relative to BoP portfolio flows (see below). Finally, fund flows are sample-based, and while the sample of reporting funds is very large, certain institutional investors are underrepresented (such as hedge funds and pension funds).

The second data source for portfolio flows is high-frequency data published by national sources in 14 EM countries and compiled by the Institute of International Finance (IIF). According to IIF estimates, these data cover about $70 \%$ of total non-resident portfolio flows to emerging markets for both equity and bond flows (Koepke and Mohammed 2014). The data are published by national central banks and stock exchanges, and are released at least at the monthly frequency (some national sources publish weekly or even daily data). These data typically feed into the calculation of countries' quarterly balance of payments data, and in some cases are identical to the lowerfrequency BoP data. An additional benefit is that the data have a much shorter publication lag than quarterly balance of payments data, which are often released several months after the end of a quarter. As Chart 1 shows, the data track total quarterly portfolio flows as measured by the IIF quite closely - much more so than EPFR fund flows data. For example, total portfolio inflows (debt and equity) in the years 2010 -2013 averaged $\$ 290$ billion per year for BoP data, which compares to $\$ 205$ billion per year for monthly BoP-consistent portfolio flows data, but only $\$ 45$ billion for EPFR's fund flows data. As such, the estimations based on portfolio flows data provide an important cross-check to the findings based on fund flows data, which in turn have the advantage that they can be disaggregated by investor type and maturity, among others. Additional charts of all the main regression variables are provided in Annex 1.

\section{Chart 1}

Portfolio Equity and Debt Flows to Emerging Economies

$\$$ billion; non-resident flows; BoP data based on IIF group of 30 emerging economies

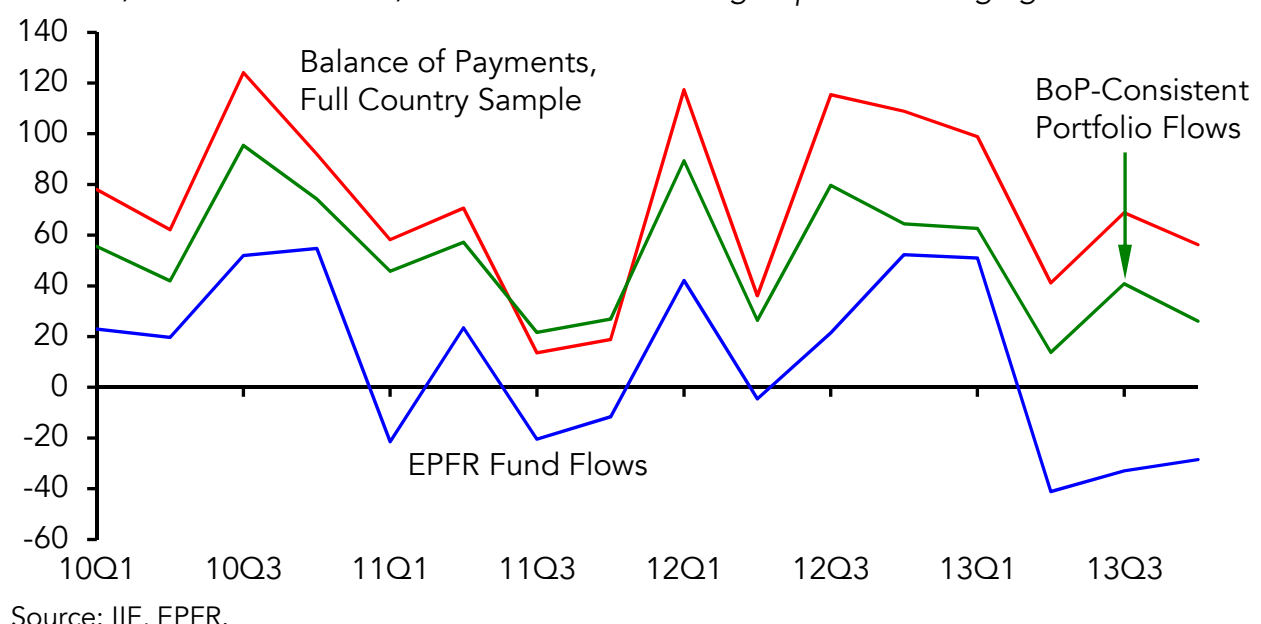

Source: IIF, EPFR. 
Expectations for U.S. policy interest rates are calculated primarily using federal funds futures contracts. These contracts can be thought of as the market expectation for the federal funds effective rate at the date specified in the contract. According to Krueger and Kuttner (1996) federal funds futures rates provide efficient forecasts of changes in the federal funds rate. An alternative measure of monetary policy expectations are eurodollar futures, which are a more liquid and are available further into the future (Rigobon and Sack 2002). Gürkaynak, Sack and Swanson (2007) find that both instruments are good predictors of changes in the federal funds target rate, with fed funds futures being the single best predictor at short time horizons. In terms of the variable specification, I use the 1-month change in the expected federal funds rate 34 months later, which is the most distant data point that is available. Using expectations for policy settings relatively far into the future is the most promising strategy because markets in certain periods did not expected any changes in the federal funds rate over the subsequent 1-2 years. This approach is also consistent with prior research on the impact of changes in federal fund futures prices on asset prices (Gürkaynak 2005). To provide an example for the calculation of the variable used in the regression model, the observation for December 2013 is based on the futures contract for October 2016, and is calculated as the average fed funds rate expected for that month during December 2013 less the average expected during November 2013. Data availability on Bloomberg for federal funds futures contracts begins in February 2011. For the period prior to February 2011, I use data on expected future interest rates from eurodollar futures contracts, which have a near-perfect correlation of 0.98 with federal funds futures contracts. The two variables are often used interchangeably in the literature (e.g., Femia et al. 2013). One limitation of eurodollar contracts is that they are only available for 4 out of 12 months in the year (March, June, September, and December). Nonetheless, robustness checks indicate that the estimation results are substantively the same when using either eurodollar futures or federal funds futures for the period when both series are available (see Section 6).

I employ control variables for country-specific and global developments consistent with the literature. As a proxy for global risk aversion I use the BBB-rated U.S. corporate bond spread over Treasuries, calculated by Bank of America Merrill Lynch ("U.S. Corporate BBB Option-Adjusted Spread") and obtained via Bloomberg. As an alternative risk variable, I use the VIX index, a measure of expected volatility in the S\&P 500 over the next 30 days, which is derived from options contracts. In terms of pull variables, I use an aggregate emerging market stock market index (the Morgan Stanley Capital International [MSCl] EM index) as a return indicator that is also able to capture cyclical conditions in EM countries to some degree. As an alternative, I use the Citigroup Economic Surprise Index for emerging markets, which is a quantitative measure of the surprise element contained in economic data releases. When newly released economic data exceed the median 
forecast in the Bloomberg consensus survey, the economic surprise index increases and vice versa. A further pull variable is the EMBIG spread, which is the yield difference (in basis points) of the J.P. Morgan Emerging Markets Bond Index Global over U.S. Treasury securities.

In alternative specifications of the model I make use several additional variables, such as total assets on the Federal Reserve's balance sheet in \$ billion, obtained via Datastream. Another variable of note is the policy interest rate differential between emerging and advanced economies, which is calculated as the GDP-weighted average of policy interest rates in 16 emerging economies that make these data available from the year 2000 onward, less the U.S. Federal Reserve's federal funds target rate. ${ }^{6}$ Data were obtained via Bloomberg and Datastream.

Empirical model: I estimate variants of the following general model:

$$
\text { Flows }_{t}=\alpha_{0}+\alpha_{1} \cdot \text { Flows }_{t-1}+\beta \cdot \text { MonPol }_{t}+\sum_{i=1}^{n} \gamma_{i} \cdot \text { Pull Factors }_{i t}+\sum_{i=1}^{n} \delta_{i} \cdot \text { Push Factors }_{i t}+\varepsilon_{t}
$$

Flows ${ }_{t}$ are net flows to EM-dedicated funds in month $\mathrm{t}$ in $\$$ billion, or alternatively net non-resident purchases of bonds and stocks from BoP-consistent portfolio flows data. Flows $\mathrm{s}_{\mathrm{t}-1}$ is the lagged dependent variable. MonPol $\mathrm{I}_{\mathrm{t}}$ is the change in federal funds futures contracts three years into the future in percentage points. "Pull Factors" are emerging market variables, while "Push Factors" are mature economy variables.

An important variant of the baseline model is a specification that tests whether the impact of shifts in monetary policy expectations is symmetric. For this purpose, I augment the baseline model by including a dummy variable D1 that is equal to 1 for months where policy rate expectations move up and a second dummy variable D2 that is equal to 1 for months where policy rate expectations move down:

$$
\begin{gathered}
\text { Flows }_{t}=\alpha_{0}+\alpha_{1} \cdot \text { Flows }_{t-1}+\boldsymbol{\beta}_{\mathbf{1}} \cdot \boldsymbol{D}_{\mathbf{1}} \cdot \text { MonPol }_{\boldsymbol{t}}+\boldsymbol{\beta}_{\mathbf{2}} \cdot \mathbf{D}_{\mathbf{2}} \cdot \text { MonPol }_{\boldsymbol{t}}+\sum_{i=1}^{n} \gamma_{i} \cdot \text { Pull Factors }_{i t} \\
+\sum_{i=1}^{n} \delta_{i} \cdot \text { Push Factor }_{i t}+\varepsilon_{t}
\end{gathered}
$$

${ }^{6}$ These countries are Brazil, Chile, China, Colombia, Czech Republic, Hong Kong, Hungary, India, Indonesia, Israel, Korea, Malaysia, the Philippines, Poland, Thailand, and Turkey. 
Sample periods: The main results are presented for two different sample periods, which are defined so as to capture the expansion phases of the U.S. business cycle (Chart 1). This is because capital flows are likely to behave differently during U.S. recessions (particularly the severe 2007-2009 recession), so these periods are excluded from the sample period. Specifically, the sample period is set to begin two quarters after the end of a U.S. recession as determined by the National Bureau of Economic Research (NBER), and to end two quarters prior to the subsequent recession. The first sample period for which results are discussed ranges from January 2010 to December 2013 and the second sample period begins in July 2002 and ends in March 2007.

\section{Chart 2}

Federal Funds Target Rate

percent per annum, recession periods as per NBER's Business Cycle Dating Committee

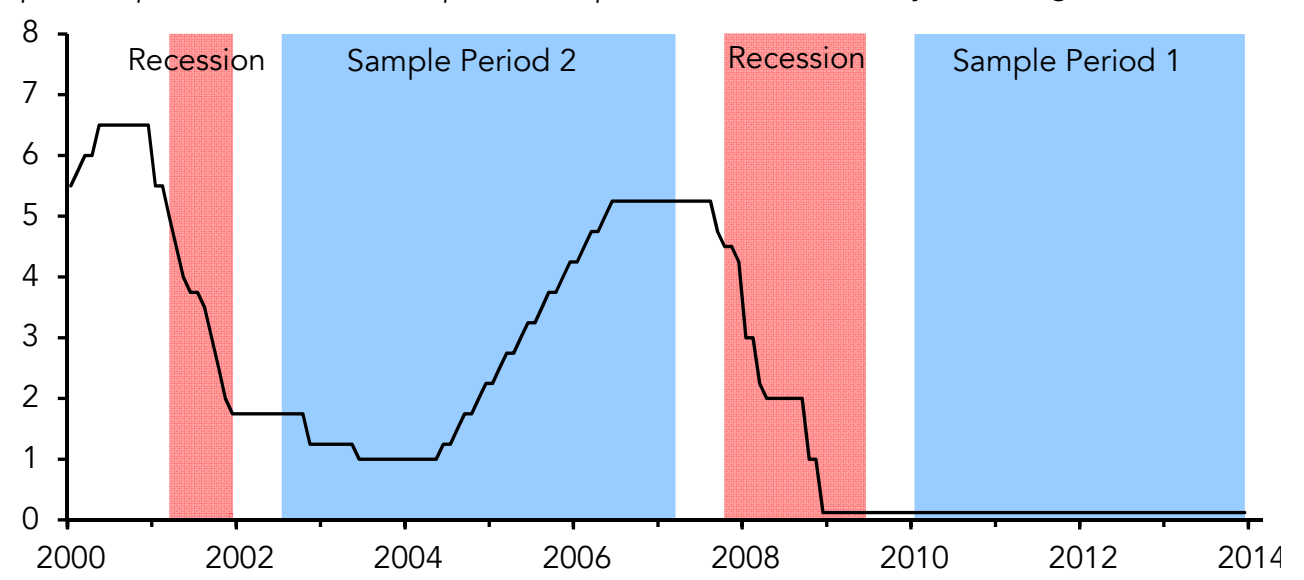

Source: Own Illustration based on Datastream and NBER.

\section{Results}

\subsection{Baseline Model: Results for the Post-Crisis Period (2010-2013)}

The baseline regression results are reported in Table 1, which shows estimations using either fund flows or international portfolio flows as the dependent variable. ${ }^{7}$ Overall, the models typically explain around $45 \%$ to $65 \%$ of the observed variation in monthly flows. The main variable of interest is the monetary policy expectations variable, which has the expected negative sign and is highly statistically significant for total flows, using either of the two flows datasets. An increase in the expected policy interest rate three years ahead leads to a reduction in EM flows of about $\$ 11.5$

\footnotetext{
${ }^{7}$ The only difference in the specification of the regressions in Table 1 is that the fund flows regressions include the lagged dependent variable, reflecting strong first-order autocorrelation of these flows. Portfolio flows are not found to be serially correlated. Instead of the lagged dependent variable a constant term is included (unlike in the fund flows estimations, where the constant term is not statistically significant).
} 
billion for EPFR fund flows and about \$15 billion for portfolio flows. The monetary policy coefficients in the regression with bond flows as the dependent variable are also highly statistically significant, while this is not the case in regressions with equity flows (in either dataset), although the coefficient does have the expected negative sign. Note, however that the monetary policy variable is significant in various alternative specifications of the equity flows regression, reported below. A potential reason why bond flows may react more strongly to interest rate surprises than equity flows is that bond prices are more closely linked to interest rates than stock prices, at least for bonds with sufficiently long remaining maturities. Consistent with this, several other studies have found a larger impact of U.S. interest rates on bond flows compared to equity flows, such as Taylor and Sarno (1997) and Dahlhaus and Vasishtha (2014).

\begin{tabular}{|c|c|c|c|c|c|c|}
\hline & \multicolumn{3}{|c|}{ EPFR Fund Flows } & \multicolumn{3}{|c|}{ BoP-Consistent Portfolio Flows } \\
\hline & Total & Debt & Equity & Total & Debt & Equity \\
\hline Constant & & & & 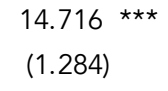 & 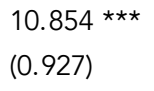 & $\begin{array}{l}3.862 \star \star \star \star \\
(0.948)\end{array}$ \\
\hline Flows $_{t-1}$ & $\begin{array}{l}0.549 \text { *** } \\
(0.096)\end{array}$ & $\begin{array}{l}0.6277^{* \star *} \\
(0.085)\end{array}$ & $\begin{array}{l}0.493 \text { *** } \\
(0.106)\end{array}$ & & & \\
\hline Monetary Policy Expectations & $\begin{array}{l}-11.459 * * \\
(4.541)\end{array}$ & $\begin{array}{l}-6.810 * * * \\
(1.624)\end{array}$ & $\begin{array}{l}-4.484 \\
(3.370)\end{array}$ & $\begin{array}{l}-15.254 * \star \star \\
(4.542)\end{array}$ & $\begin{array}{l}-10.70 * \star * \\
(3.280)\end{array}$ & $\begin{array}{l}-4.553 \\
(3.353)\end{array}$ \\
\hline BBB Spread & $\begin{array}{c}-14.820 \text { ** } \\
(9.194)\end{array}$ & $\begin{array}{l}-10.466 \text { *** } \\
(3.144)\end{array}$ & $\begin{array}{l}-5.497 \\
(7.100)\end{array}$ & $\begin{array}{l}-38.6088^{* * *} \\
(8.291)\end{array}$ & $\begin{array}{l}-22.97 \text { *** } \\
(5.987)\end{array}$ & $\begin{array}{l}-15.634 \text { ** } \\
(6.121)\end{array}$ \\
\hline $\mathrm{MSCl}$ EM & $\begin{array}{l}1.163 \text { *** } \\
(0.246)\end{array}$ & $\begin{array}{l}0.278^{\star \star \star} \\
(0.089)\end{array}$ & $\begin{array}{l}0.878 \text { *** } \\
(0.185)\end{array}$ & $\begin{array}{l}1.299 * \star \star \\
(0.230)\end{array}$ & $\begin{array}{l}0.52^{\star \star \star} \\
(0.166)\end{array}$ & $\begin{array}{l}0.782 \text { *** } \\
(0.170)\end{array}$ \\
\hline Adjusted $R^{2}$ & 0.61 & 0.65 & 0.54 & 0.63 & 0.44 & 0.45 \\
\hline Number of Observations & 48 & 48 & 48 & 48 & 48 & 48 \\
\hline
\end{tabular}

Notes: Asterisks denote significance at the $10 \%, 5 \%$ and $1 \%$ level for 1, 2, and 3 asterisks, respectively. Standard errors are in parentheses. Models were estimated using monthly data for January 2010 to December 2013. Functional forms are based on standard stationarity tests for all variables (Augmented Dickey-Fuller tests). For fund flows, the dependent variable is net flows to EM-dedicated funds as reported by EPFR Global, while for portfolio flows it is net non-resident purchases of EM securities. Flowst 1 is the lagged dependent variable. Monetary Policy Expectations refers to the change in the federal funds futures contract three years into the future. BBB Spread is the change in the yield difference on U.S. BBB-rated corporate bonds relative to U.S. Treasuries. MSCI EM is the percent change in the Morgan Stanley Capital International EM stock market index from the prior month. EMBIG Spread is the change from the prior month in the yield (in basis points) of the JPMorgan Emerging Markets Bond Index Global (EMBIG). For further details, see the data descriptions in Section 4. 
In terms of the other explanatory variables, an increase in global risk aversion is associated with a reduction in both fund flows and portfolio flows, as expected. The variable is statistically highly significant and economically important in all specifications except one (for equity fund flows). An increase in the BBB spread by one percentage point is associated with a reduction in total fund flows of $\$ 21$ billion and a reduction in total portfolio flows of $\$ 39$ billion. In addition, there is a strong relationship between the local stock market index and investment flows, which has the expected positive sign. A one percent increase in EM stock prices is associated with additional fund flows of about $\$ 1.2$ billion and increased portfolio flows of $\$ 1.3$ billion.

Results for several alternative specifications of the baseline regressions are reported in Tables $2 a$ and $2 \mathrm{~b}$ for bond flows and Tables $3 \mathrm{a}$ and $3 \mathrm{~b}$ for equity flows. Fund flows consistently exhibit strong positive first-order autocorrelation, indicating momentum in investor behavior. This has implications for interpreting the magnitude of the estimated coefficients on the other regression variables. It implies that an initial shock in one of the drivers will impact portfolio flows not just in the same month, but also in the following months (with a diminishing impact over time for an autocorrelation coefficient between 0 and 1). Therefore, the coefficient estimates on the various push and pull drivers indicate the short run (contemporaneous) impact, while the long run impact is a multiple of the short run impact whose size depends on the autocorrelation coefficient (Greene 2008). ${ }^{8}$

For bond fund flows (Table 2a), the model typically explains around $60-65 \%$ of the observed variation in flows. Market expectations for Fed policy rates are a statistically highly significant and economically important explanatory variable. In all specifications shown in Table 2a the significance level is below $1 \%$. A one percentage point upward shift in market expectations for the federal funds rate three years out is estimated to be associated with net portfolio debt outflows of about \$6-7 billion contemporaneously. The total (long term) impact is estimated to range between $\$ 15$ and $\$ 18$ billion across the various model specifications. To put these estimates into context, total annual inflows to bond funds as reported by EPFR averaged $\$ 26$ billion from 2010-2013. Table $2 \mathrm{~b}$ shows that the estimated impact on portfolio debt flows ranges from $\$ 10$ to $\$ 15$ billion, with the coefficient significant across model specifications.

In terms of the other explanatory variables, the impact of global risk aversion is estimated using either the BBB spread or the VIX. While the model fit tends to be slightly better when using the BBB spread, both proxies for global risk yield quite similar results, with an increase in stock market

\footnotetext{
${ }^{8}$ For a positive autocorrelation coefficient $\alpha_{1}$, the multiplier can be calculated as $\frac{1}{\left(1-\alpha_{1}\right)}$, i.e. the long term impact is $L T_{-} I m p a c t=\frac{S T_{-} I m p a c t}{\left(1-\alpha_{1}\right)}$. For example, for the correlation coefficient of 0.627 reported in the first regression of Table $2 \mathrm{a}$, the multiplier is 2.68 .
} 
Table 2a: Estimation Results for Debt Fund Flows - Baseline Model (2010-2013)

\begin{tabular}{|c|c|c|c|c|}
\hline & (1) & (2) & (3) & (4) \\
\hline Flows $_{t-1}$ & $\begin{array}{l}0.627^{\star * * *} \\
(0.085)\end{array}$ & $\begin{array}{l}0.635 \text { *** } \\
(0.089)\end{array}$ & $\begin{array}{l}0.573 \text { *** } \\
(0.092)\end{array}$ & $\begin{array}{l}0.691 \text { *** } \\
(0.091)\end{array}$ \\
\hline Monetary Policy Expectations & $\begin{array}{l}-6.810 * \star \star \\
(1.624)\end{array}$ & $\begin{array}{l}-6.458 \text { *** } \\
(1.705)\end{array}$ & $\begin{array}{l}-6.299 * * * \\
(1.885)\end{array}$ & $\begin{array}{l}-6.3277^{\star \star \star} \\
(1.796)\end{array}$ \\
\hline BBB Spread & $\begin{array}{l}-10.466 \text { *** } \\
(3.144)\end{array}$ & $\begin{array}{l}-10.300 \text { *** } \\
(3.280)\end{array}$ & $\begin{array}{l}-13.858 \text { *** } \\
(3.269)\end{array}$ & \\
\hline $\mathrm{MSCI} \mathrm{EM}$ & $\begin{array}{l}0.278^{* \star *} \\
(0.089)\end{array}$ & & & $\begin{array}{l}0.280^{* \star \star} \\
(0.102)\end{array}$ \\
\hline EMBIG Spread & & $\begin{array}{l}-0.052 \text { *** } \\
(0.018)\end{array}$ & & \\
\hline EM Economic Surprise Index & & & $\begin{array}{r}0.014 \\
(0.021)\end{array}$ & \\
\hline VIX & & & & $\begin{array}{l}-0.340 \text { ** } \\
(0.153)\end{array}$ \\
\hline Adjusted R & 0.65 & 0.63 & 0.58 & 0.60 \\
\hline Number of Observations & 48 & 48 & 48 & 48 \\
\hline
\end{tabular}

Table 2b: Estimation Results for Portfolio Debt Flows - Baseline Model (2010-2013)

(1)

(2)

(3)

(4)

\begin{tabular}{|c|c|c|c|c|}
\hline Constant & $\begin{array}{l}14.716 \text { ***} \\
(1.284)\end{array}$ & 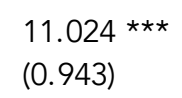 & $\begin{array}{l}10.921 \text { *** } \\
(1.024)\end{array}$ & 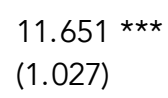 \\
\hline Monetary Policy Expectations & $\begin{array}{l}-15.254 * \star \star \\
(4.542)\end{array}$ & $\begin{array}{l}-10.344 * * * \\
(3.326)\end{array}$ & $\begin{array}{l}-9.914 \text { ** } \\
(3.794)\end{array}$ & $\begin{array}{l}-6.477 \text { * } \\
(3.627)\end{array}$ \\
\hline BBB Spread & $\begin{array}{l}-38.608 \text { *** } \\
(8.291)\end{array}$ & $\begin{array}{l}-22.953 * * * \\
(6.158)\end{array}$ & $\begin{array}{l}-29.922 \text { *** } \\
(6.353)\end{array}$ & \\
\hline $\mathrm{MSCI} \mathrm{EM}$ & $\begin{array}{l}1.299 * * * \\
(0.230)\end{array}$ & & & $\begin{array}{l}1.007 \text { *** } \\
(0.242)\end{array}$ \\
\hline EMBIG Spread & & $\begin{array}{l}-0.094 \text { *** } \\
(0.033)\end{array}$ & & \\
\hline EM Economic Surprise Index & & & $\begin{array}{l}-0.006 \\
-0.041\end{array}$ & \\
\hline VIX & & & & $\begin{array}{r}0.467 \\
(0.302)\end{array}$ \\
\hline Adjusted $R^{2}$ & 0.63 & 0.42 & 0.32 & 0.29 \\
\hline Number of Observations & 48 & 48 & 48 & 48 \\
\hline
\end{tabular}

For explanations, see notes under Table 1. 
volatility being associated with a lower volume of flows into EM-dedicated funds.

Regarding EM pull variables, there is a strong relationship between the local stock market index and bond flows, which has the expected positive sign. As an alternative, the EMBIG spread is used as a control variable, which is also highly significant and has the expected negative sign. Both the $\mathrm{MSCl}$ stock index and the EMBIG spread are likely to incorporate new information about changing local economic and financial conditions quickly and effectively. However, both variables are likely to be influenced by global financial developments, such as fluctuations in world equity and bond markets. Therefore, in a further variation of the core model, I use a control variable that should not be influenced by global financial conditions - an EM economic surprise index. Positive economic data surprises in emerging markets are associated with increased bond inflows. While the variable carries the expected sign, it is not statistically significant at the $10 \%$ level for bond flows (although it is significant for equity flows, see below). In all these specifications, the choice of the "pull" control variable has only a small impact on the estimated coefficient for monetary policy expectations. $^{9}$

Turning to equity flows, the estimated coefficients generally show the same sign as for bond flows, but the overall fit of the model is less good (Tables 3a and 3b). This may be partly explained by the finding that equity flows exhibit somewhat lower positive autocorrelation than bond flows. The estimated coefficient on market expectations for U.S. monetary policy is somewhat lower than for bond flows, and the variable is statistically significant only for fund flows when using the VIX index as a control variable. Interestingly, the emerging market economic surprise index is a significant determinant of portfolio equity flows, with positive data surprises resulting in greater inflows to emerging economies. This is a noteworthy finding since in the literature there are no firmly established macro pull drivers at the monthly frequency, given that GDP estimates and many other important macro indicators are typically published at the quarterly frequency (Koepke 2015).

\footnotetext{
${ }^{9}$ I tested several additional proxies for EM macro conditions, such as the consensus forecast for real GDP growth and purchasing manager indices. While there was no statistically robust evidence that these variables are drivers of portfolio flows over the sample period, the estimation results for the monetary policy expectations variable are substantively the same when using these control variables.
} 
Table 3a: Estimation Results for Equity Fund Flows - Baseline Model (2010-2013)

(1)

(2)

(3)

(4)

Flows $_{\mathrm{t}-1}$

$\begin{array}{cccc}0.493^{\star * \star} & 0.389^{* \star \star} & 0.392^{\star \star \star} & 0.515^{\star \star \star} \\ (0.106) & (0.127) & (0.125) & (0.091)\end{array}$

Monetary Policy Expectations

$-4.484$

$-1.260$

-6.466 **

(3.370)

(4.219)

(3.196)

BBB Spread

$-5.497$

-16.577 **

$-15.825^{\star *}$

(7.100)

(7.891)

(7.401)

MSCI EM

0.878 ***

$0.678 * * *$

(0.185)

$(0.184)$

EM Economic Surprise Index

$\begin{array}{cc}0.083 * & 0.087 \text { * } \\ (0.049) & (0.046)\end{array}$

VIX

$-0.755 * * *$

(0.277)

\begin{tabular}{lrrrr}
\hline Adjusted $R^{2}$ & 0.54 & 0.35 & 0.36 & 0.60 \\
Number of Observations & 48 & 48 & 48 & 48 \\
\hline
\end{tabular}

Table 3b: Estimation Results for Portfolio Equity Flows - Baseline Model (2010-2013)

Constant

Monetary Policy Expectations

BBB Spread

$\mathrm{MSCl} \mathrm{EM}$

EM Economic Surprise Index

VIX
(1)

(2)

$3.862 * \star \star$

(0.948)

$-4.553$

(3.353)

-15.634 **

(6.121)

0.782 ***

(0.170)

(3)

(4)

$\begin{array}{lc}4.002 * \star \star & 4.105 * \star \star \\ (1.122) & (1.036) \\ -1.059 & \\ (4.156) & \\ 23.143 * \star \star & -22.503 * \star \star \\ (6.959) & (6.421) \\ & \end{array}$

4.514 ***

(1.190)

1.458

(4.378)

$\begin{array}{rrr}0.071 & 0.075 * & 0.092 \text { * } \\ (0.044) & (0.042) & (0.047)\end{array}$

Adjusted $R^{2}$

0.45

0.23

0.25

-0.477 *

(0.255)

Number of Observations

48

48

48

0.11

48

For explanations, see notes under Table 1. 


\subsection{Asymmetric Model: Results for the Post-Crisis Period (2010-2013)}

In order to test whether the impact of shifts in monetary policy expectations is symmetric, the baseline model is augmented with a dummy variable D1 that is equal to 1 for months where policy rate expectations move up and a second dummy variable D2 that is equal to 1 for months where policy rate expectations move down. The results for bond and equity flows in the 2010-2013 period are reported in Tables $4 \mathrm{a} / \mathrm{b}$ and $5 \mathrm{a} / \mathrm{b}$ of the appendix, respectively.

Overall, the estimation results suggest that the adverse effect on EM portfolio inflows resulting from a shift towards tighter monetary policy is much greater than the boost from a shift towards easier policy. For bond fund flows, the estimated coefficient for shifts towards tighter policy is about twice as high as the coefficient for shifts towards easier policy, while for portfolio debt flows the multiple typically ranges between 5 and 10. For bond fund flows, both coefficients are statistically significant in all specifications shown in Table 4a, while for portfolio debt flows the coefficient on downward shifts in Fed policy expectations is not significant. For equity flows, the estimated coefficient on shifts towards tighter Fed policy is also greater than for shifts towards easier Fed policy (for both fund flows and portfolio flows). However, the coefficient is statistically significant only in some specifications.

A possible explanation for this asymmetric effect relates to the fact that Fed easing by design tends to encourage risk-taking by investors. When investors are pushed into risky assets, as opposed to being attracted by the intrinsic qualities of these assets, they may be less committed to those positions and thus more likely to unwind them when the tide turns. Another possibility is that it may take longer for investors to increase their EM allocations than to unwind them, for example because of information asymmetries when entering a market. This would mean that the total effect of shifts in expectations towards easier policy may be not quite as different in magnitude compared to shifts towards tighter policy, but the adjustment may be less rapid.

\subsection{Results for the Pre-Crisis Period (July 2002 - March 2007)}

The regression results for the pre-crisis period are reported in Tables 6 to 9 in the appendix. Data for this period are only available for fund flows. In terms of the baseline regressions, all coefficients that were statistically significant in the post-crisis period have the same sign in the pre-crisis period, but they generally have a lower level of statistical significance. This applies in particular to the monetary policy expectations variable. For bond flows, the estimated coefficient suggests a short-term impact 
of $\$ 0.2$ to $\$ 0.5$ billion dollars for a one percentage point downward shift in the expected policy rate. For equity flows, the estimate is between $\$ 0$ to $\$ 0.2$ billon. In both estimations, the coefficient is not statistically significant. One possible explanation for the lower coefficient estimate is that actual and especially measured fund flows were significantly smaller in the mid-2000s than post-crisis (measured flows have increased since the mid-2000s in part because the sample of mutual funds reporting to EPFR expanded over time). Another limitation is that the bond flows time series published by EPFR only begins in November 2003. It is also important to note that the Fed's mid-2000s policy tightening cycle was exceptional in that it occurred in a very steady and predictable fashion, reducing the scope for gyrations in expected future policy rates. Specifically, the federal funds rate was raised by 25 basis points at each of the 17 policy meetings from June 2004 to June 2006. The Fed leadership has recently distanced itself from this approach to policy-making, indicating that prospective rate hikes are unlikely to occur in the same steady and predictable fashion, and instead will be data-dependent (e.g., Federal Reserve Board 2014).

Both the BBB spread and the stock market index were statistically significant and economically important drivers of bond flows in the pre-crisis period. Again, the coefficient estimates are smaller than in the post-crisis period, likely reflecting the growing volume of actual and measured capital flows over that period. For equity flows, the estimated coefficient for the risk variable is statistically different from zero only when using the economic surprise index as a control variable.

The asymmetric model for the impact of shifts in policy expectations yields different results for the pre-crisis period than after the global financial crisis. For bond flows, shifts in market expectations towards easier monetary policy have a statistically significant (positive) impact on portfolio flows to emerging markets. However, the estimated coefficient for upward shifts in policy rate expectations is not statistically significantly different from zero. For equity flows, changes in monetary policy expectations do not seem to have been a significant driver in the pre-crisis period. A possible explanation for the apparent differences in market behavior in the two sample periods is the Fed's use of forward guidance in the latter period, which shifted market attention squarely on the likely course of future monetary policy.

\subsection{Impact of Fed Asset Purchases}

The impact of the Fed's large-scale asset purchase programs on EM flows has received significant attention in recent years. It is plausible that asset purchases impact those flows above and beyond the effect captured by the Fed policy expectations channel. In order to test this hypothesis, I include 
as an additional regressor total Fed assets for a particular month. Based on standard stationarity tests, the variable is specified as the second difference of the level of assets held by the Fed, i.e. the change in the pace of asset purchases.

The results are reported in Table 10 of the appendix. There is evidence that asset purchases do have an impact on EM fund flows above and beyond the expectations channel. Across the four core model specifications (for debt and equity, in the baseline and the asymmetric model), the estimated coefficient is consistently positive and statistically significant at the $10 \%$ level. The estimation results can usefully be applied to the Federal Reserve's reduction in the pace of asset purchases during the course of 2014 . The coefficient estimates suggest that the short-term impact of a $\$ 10$ billion reduction in the monthly pace of asset purchases is associated with a reduction in EM fund flows of $\$ 0.7$ billion. Given the positive autocorrelation of fund flows, the long-term impact of such a reduction is estimated at about $\$ 2$ billion.

\subsection{Policy Interest Rate Differentials}

I also test the policy interest rate differential between emerging and advanced economies as an additional potential driver of portfolio flows. This variable is of particular interest in the context of the "carry trade" investment strategy, where an investor borrows money in a low-yielding currency in order to invest it in a high-yielding currency (Galati et al. 2007). This results in a profit so long as exchange rates movements do not offset these gains (as would be predicted by the theory of uncovered interest parity, Fama 1984).

The regression results for the models that include the policy interest rate differential are reported in Table 11 of the appendix. There is no evidence in support of the hypothesis that policy interest rate differentials have been a driver of aggregate emerging market portfolio equity or debt flows in either the pre-crisis or the post-crisis period. In fact, the estimated coefficient on the proxy for the interest rate differential is often negative (but not statistically significant), at odds with the carry trade hypothesis. As a robustness check, I also tested this variable using policy interest rates for a broader range of emerging economies in the post-crisis period, where additional country data is available. The results remained substantively unchanged, however.

A few words of caution are in order against drawing premature conclusions from the lack of empirical evidence for the carry trade effects. Strategies like the carry trade are arguably more likely to be pursued by a subgroup of institutional investors, notably hedge funds, which are typically very 
secretive about their investments and thus are unlikely to be included in EPFR's sample of reporting funds (Galati and Melvin, 2004). Another limitation is that the empirical model is best-suited for capturing the contemporaneous effect of a change in the policy interest rate differential, while in reality this effect may be playing out over a longer time period. In an attempt to capture such a dynamic effect, I tested whether lagging the policy interest rate differential by one period would yield a different result, which was not the case.

\subsection{Institutional Investors vs. Retail Investors}

The fund flows dataset used for the dependent variable also includes a breakdown of flows by investor type, which allows a distinction between actions by institutional investors and retail investors. The classification is primarily based on the share classes made available to investors by mutual funds and exchange-traded funds. In contrast to the retail share class, the institutional share class generally has a very high minimum investment requirement, implying that typically (though not always) the investor is a firm rather than an individual.

Tables 12 and 13 in the Appendix show the estimation results by investor type for the 2010-2013 sample period. Overall, both investor types appear to respond to EM local conditions and external developments in broadly similar ways. In the baseline model for equity flows, changes in monetary policy expectations seem to have a greater effect on institutional investors, while the variable is not statistically significant for retail investors. This does not apply to debt flows, however, where there is robust statistical evidence that both investor types respond to changes in monetary policy expectations.

The asymmetric model suggests that the tendency of market participants to respond disproportionately to a shift in expectations towards tighter monetary policy is primarily driven by retail investors. Both equity and debt flows from retail investors seem to respond much more strongly to an anticipation of tighter Fed policy than to shifts in the opposite direction. While the evidence is not statistically robust for equity flows from institutional investors, the estimated coefficients for upward shifts in expectations for the federal funds rate are modestly greater than the coefficient on downward shifts. For debt flows, the estimated coefficients on the monetary policy expectations variable are statistically significant, and there is tentative evidence of a disproportionately strong response of institution investors to "bad news" from the Fed, though the two coefficients are relatively close to each other. 


\section{Robustness Checks}

A broad range of robustness checks were conducted to ensure the validity of all core findings. It is worth noting that the baseline and the augmented models typically explain around $40-60 \%$ of the variation in portfolio fund flows over time, leaving a substantial portion to be explained by other factors. I tested a number of additional country-specific macro variables to control for local conditions in emerging markets, such as manufacturing purchasing manager indices (PMIs) and changes in the consensus forecast for real GDP growth in emerging markets. The core estimation results are substantively the same when using either of these alternative control variables. In terms of the variables themselves, however, there is no conclusive evidence that PMls or changes in growth expectations are in fact driving portfolio flows at the monthly frequency.

I also tested three alternative "push" variables in place of the monetary policy expectations variable that are more closely aligned with the traditional variables used in the literature. These variables are (1) changes in the slope of the U.S. yield curve as measured by the difference between the yield on 10-year bonds and 2-year bonds, (2) changes in the term premium of 10-year U.S. Treasury bonds, as calculated by Kim and Wright (2005), and (3) changes in 3-year Treasury yields (i.e. using the same time horizon as for fed funds futures contracts). For fund flows, these additional estimation results are reported in Tables $14-16$ of the annex. All three variables are statistically highly significant for bond flows, but for equity flows only the coefficient on 3-year Treasury yields is statistically significant. For both types of flows, the asymmetric model does not indicate that increases in 3-year Treasury yields, the term premium or the slope of the yield curve have a disproportionately strong impact on EM flows (compared to declines in the term premium or the slope of the yield curve, respectively). This may suggest that federal funds futures contracts are a "purer" measure of the push effect that investors respond to (in the sense discussed in Section 3).

Another robustness check relates to the maturity of bonds. Arguably, changes in expectations for future monetary policy should have a stronger impact on flows into bonds with long remaining maturities, while short-dated bonds may not be much affected by expected changes in policy interest rates. EPFR provides limited data on the bond flows by maturity, which are broken down into three classes of remaining maturities: short term, intermediate term and long term. For the bulk of EM bond flows, however, maturities are not reported by the participating funds. In practice, only the sample for short term maturities seems sufficiently large (in terms of assets under management) for statistical analysis. Regressions with short-term bond flows as the dependent variable are reported in Table 17 of the annex. The results are consistent with the hypothesis that short-dated bonds are less impacted by changes in monetary policy expectations, given that in most specifications, the 
coefficient on the monetary policy expectations variable is not statistically significantly different from zero.

Conceptually, it is possible that the impact of shifts in monetary policy expectations depends on the trigger of those shifts, which could either be a perceived change in the economic outlook or a perceived change in the Fed's reaction function. To test this hypothesis, I included a U.S. economic surprise index as an additional control variable in order to take account of the "quality" of the U.S. economic data flow. However, the results were unaffected and the estimated coefficient for this control variable was not statistically significantly different from zero.

Additional robustness checks included variations in the sample period, for example by estimating the post-crisis model from 2011 (rather than 2010) to 2013 and estimating the pre-crisis model from 2003 to 2006 . The empirical results were not sensitive to these variations in the sample period. For the post-crisis sample period, I also tested eurodollar futures as an alternative proxy for changes in monetary policy expectations. These contracts have a near-perfect correlation of 0.98 with federal funds futures contracts and the two variables are often used interchangeably in the literature. The results were not affected by the choice of variable. Furthermore, I also varied the calculation of the monetary policy expectations variable by using the end-of-month value rather than the monthly average. The results are essentially identical in these two specifications.

\section{Conclusion}

The findings presented in this paper provide robust evidence that changes in market expectations for U.S. monetary policy are an important determinant of portfolio flows to EM economies, especially bond flows. There is also strong empirical support for the existence of an asymmetric impact in the post-crisis period, where shifts in expectations towards tighter monetary policy have a much stronger adverse impact on portfolio bond flows (and to a lesser extent equity flows) than the boost that comes from shifts towards easier policy. These results hold for two alternative high frequency measures of investment flows, namely EPFR fund flows data, which have enjoyed growing popularity in academic and policy research in recent years, and a novel dataset on BoP-consistent portfolio flows data compiled by the Institute of International Finance.

In focusing on the role of monetary policy surprises, the findings of this study suggest that a more nuanced reading of the existing empirical literature may be needed. In the existing literature, the 
prospect of Fed tightening is typically portrayed as an unambiguous adverse factor for capital flows to emerging markets. By contrast, the "surprise view" advanced in this study suggests that Fed interest rate hikes per se may not have any effect on EM capital flows at all. Instead, the empirical results suggest that the impact on capital flows stems primarily from the evolution of market expectations for future Fed policy interest rates.

To be sure, more research is needed to ascertain the relative impact of expected versus unexpected interest rate increases on capital flows. While this study has provided robust evidence that the unanticipated portion of interest rate movements affects EM portfolio flows, it has not directly addressed whether anticipated interest rate changes have any such impact. This would be a useful avenue for future research. An empirical assessment would likely need to be based on lowerfrequency data than was used in the present study, such as annual data. This is because anticipated interest rate changes are greater at longer-term horizons and thus typically account for a larger portion of observed interest rate changes at lower data frequencies (see Section 3). Prior work based on low-frequency data provides some support for the notion that anticipated interest rate increases do not have a statistically significant impact on EM portfolio flows (e.g., Hernandez et al. 2001). Since prior work did not distinguish between anticipated and unanticipated interest rate increases, this support is tentative and more targeted analysis is needed.

The findings in this study also highlight the potential usefulness of federal funds futures contracts as planning tool for policy analysis and risk management. Policymakers and investors can use federal funds futures contracts to monitor monetary policy surprises in real time and gauge the likely impact on portfolio flows to emerging markets. Building on this framework, the Institute of International Finance makes available timely high-frequency estimates of portfolio flows to EMs that are estimated based on a broad range of data, including fed funds futures pricing (Koepke and Mohammed 2014). Fed funds futures contracts can also be used to construct risk scenarios about the future course of Fed policy in order to quantify how a potential shift in the expected rate path is likely to impact portfolio flows.

A reinterpretation of the empirical literature in line with the "surprise view" would have a range of important policy implications. On the one hand, this new perspective provides reassurance at the current juncture, where the Fed is set to embark on sustained interest rate hiking cycle. Against the conventional wisdom, policy risks are not one-sided. While capital flows could reverse if Fed exit takes place faster than markets anticipate, it is equally possibly that capital flows will be boosted by a slower-than-expected tightening cycle. In either case, emerging market policymakers may need to lean against the wind by making judicious use of monetary, fiscal, and exchange rate policies. 
On the other hand, the finding that shifts in Fed policy expectations have an asymmetric impact depending on the direction of the shift suggests caution on the part of EM policymakers.

Asymmetric market responses mean that the cumulative effect of Fed policy on portfolio inflows to emerging markets is more likely to be negative over time. Disproportionate spillovers from an upward shift in Fed policy expectations add to the tail risks of sudden stops in the supply of external financing available to emerging economies. This risk serves to highlight the importance of maintaining sufficient policy space and encouraging prudent risk management practices to buffer the impact of external pressures. For example, EM central banks should maintain sufficient foreign exchange reserves to counteract excessive FX volatility if needed, governments should use prudent fiscal policy and avoid excessive dependence on external financing, and businesses should reduce currency mismatches between liabilities and assets to shield themselves from swings in FX rates.

The role of market expectations also has important implications for monetary policy-making by the Fed. The findings of this study highlight the importance of effective Fed communication and appropriate anchoring of market expectations. This is particularly noteworthy in the context of the ongoing policy debate about the merits and risks of central bank forward guidance (see, for example, Woodford 2012). In recent years, the Fed has attempted to provide a stronger anchor for market expectations via its forward guidance, by describing in both quantitative and qualitative terms how monetary policy is expected to evolve under future economic conditions. The Fed's efforts thus far appear to have had only limited success in stabilizing market expectations of future monetary policy, judging by the observed gyrations in federal funds futures contracts (see Charts 3 and 4 in the annex) and comments by participants of the Federal Open Market Committee, which suggest that market expectations have at times moved in the opposite direction of the Fed's own assessment. ${ }^{10}$ During the 2013 "taper tantrum" swings in market expectations for the future course of the federal funds rate seem to have taken a significant toll on emerging markets as portfolio flows reversed - a toll that could be avoided in the future if the Fed manages to anchor expectations more effectively.

\footnotetext{
${ }^{10}$ For example, the policy meeting minutes of the Fed's April/May 2013 meeting minutes state: "A few members expressed concerns that investor expectations of the cumulative size of the asset purchase program appeared to have increased somewhat since it was launched last September despite a notable decline in the unemployment rate and other improvements in the labor market since then" (Federal Reserve, 2013a). On other occasions, markets appear to have misread the Fed's policy intentions until views were confronted with Fed policy actions, such as the September 2013 decision to delay the widely expected tapering of asset purchases, which resulted in a sharp decline in the expected path of short-term interest rates that, according to the FOMC minutes, "brought the path more closely into alignment with the Committee's forward guidance" (Federal Reserve, 2013b).
} 


\section{References}

Ahlquist, John S. 2006. "Economic Policy, Institutions, and Capital Flows: Portfolio and Direct Investment Flows in Developing Countries." International Studies Quarterly 50.3: 681-704.

Ahmed, Shaghil, and Andrei Zlate. 2013. "Capital Flows to Emerging Market Economies: a Brave New World?" Working Paper No. 1081, Board of Governors of the Federal Reserve System.

Ananchotikul, Nasha, and Longmei Zhang. 2014. "Portfolio Flows, Global Risk Aversion and Asset Prices in Emerging Markets." No. 14-156. International Monetary Fund.

Bernanke, Ben S., and Kenneth N. Kuttner. 2005. "What Explains the Stock Market's Reaction to Federal Reserve Policy?" The Journal of Finance 60, no. 3: 1221-1257.

Bluedorn, John C., Rupa Duttagupta, Jaime Guajardo, and Petia Topalova. 2013. "Capital Flows are Fickle: Anytime, Anywhere." No. 13-183. International Monetary Fund.

Brandt, Cameron, Robin Koepke, and Saacha Mohammed. 2015. "Emerging Market Portfolio Flows: Lessons from 2014." Joint IIF-EPFR Research Note.

Bruno, Valentina, and Hyun Song Shin. 2015. "Capital Flows and the Risk-Taking Channel of Monetary Policy." Journal of Monetary Economics 71, no 1: 119-132.

Calvo, Guillermo A., Leonardo Leiderman, and Carmen M. Reinhart. 1993. "Capital Inflows and Real Exchange Rate Appreciation in Latin America: the Role of External Factors." Staff Papers International Monetary Fund: 108-151.

Dahlhaus, Tatjana, and Garima Vasishtha. 2014. "The Impact of US Monetary Policy Normalization on Capital Flows to Emerging-Market Economies." No. 14-53.

De Vita, Glauco, and Khine S. Kyaw. 2008a. "Determinants of Capital Flows to Developing Countries: a Structural VAR Analysis." Journal of Economic Studies 35, no. 4: 304-322.

Cook, T., Hahn, T., 1989. The Effect of Changes in the Federal Funds Rate Target on Market Interest Rates in the 1970s. Journal of Monetary Economics 24, 331-351.

Emerging Portfolio Fund Research Global. 2015. "Frequently Asked Questions / Glossary." Accessed on April 6, 2015 at: http://epfr.com/faq.aspx.

Fama, Eugene F. 1984 "Forward and Spot Exchange Rates." Journal of Monetary Economics 14.3: 319-338.

Federal Reserve. 2013a. "Minutes of the Federal Open Market Committee April 30-May 1, 2013."

Federal Reserve. 2013b. "Minutes of the Federal Open Market Committee October 29-30, 2013."

Federal Reserve. 2014. "Transcript of Chair Yellen's FOMC Press Conference. December 17, 2014."

Femia, Katherine, Friedman, Steven, and Sack, Brian. 2013. "The Effects of Policy Guidance on Perceptions of the Fed's Reaction Function." Federal Reserve Bank of New York Staff Report, 652. 
Fernández -Arias, Eduardo. 1996. "The New Wave of Private Capital Inflows: Push or Pull?" Journal of Development Economics 48, no. 2: 389-418.

Feroli, Michael, Anil K. Kashyap, Kermit L. Schoenholtz, and Hyun Song Shin. 2014. "Market

Tantrums and Monetary Policy." Chicago Booth Research Paper 14-09.

Ferucci, Gianluigi, Valerie Herzberg, Farouk Soussa, and Ashley Taylor. 2004. "Understanding Capital Flows." Bank of England. Financial Stability Review, June 2004.

Forbes, Kristin J., and Francis E. Warnock. 2012. "Capital Flow Waves: Surges, Stops, Flight, and Retrenchment." Journal of International Economics 88, no. 2: 235-251.

Fratzscher, Marcel, M. Lo Duca, and Roland Straub. 2012. "Quantitative Easing, Portfolio Choice and International Capital Flows." Draft, European Central Bank, Frankfurt.

Fratzscher, Marcel. 2012. "Capital Flows, Push versus Pull Factors and the Global Financial Crisis." Journal of International Economics 88, no. 2: 341-356.

Galati, Gabriele and Michael Melvin. 2004. "Why Has FX Trading Surged? Explaining the 2004 Triennial Survey." BIS Quarterly Review, December: 67-74.

Galati, Gabriele, Alexandra Heath, and Patrick McGuire. 2007. "Evidence of Carry Trade Activity." BIS Quarterly Review 3: 27-41.

Greene, William H. 2008. "Econometric Analysis."

Gupta, Dipak Das, and Dilip Ratha. 2000. "What Factors Appear to Drive Private Capital Flows to Developing Countries? And how Does Official Lending Respond?" Vol. 2392. World Bank Publications.

Gürkaynak, Refet S. 2005. "Using Federal Funds Futures Contracts for Monetary Policy Analysis."

Gürkaynak, Refet S., Brian P. Sack, and Eric T. Swanson. 2007. "Market-Based Measures of Monetary Policy Expectations." Journal of Business and Economic Statistics 25, no. 2.

Hamilton, James D. 2008. "Daily Monetary Policy Shocks and New Home Sales." Journal of Monetary Economics 55, no. 7: 1171-1190.

Hernandez, Leonardo, Pamela Mellado, and Rodrigo Valdes. 2001. "Determinants of Private Capital Flows in the 1970s and 1990s: Is there Evidence of Contagion?" IMF Working Paper no. 01/64.

Institute of International Finance. 2013. "Capital Flows to Emerging Market Economies." IIF Research Note, October 2013.

Institute of International Finance. 2014. "Capital Flows to Emerging Market Economies." IIF Research Note, May 2014.

International Monetary Fund. 2010. "Balance of Payments Manual."

Jeanneau, Serge, and Marian Micu. 2002. "Determinants of International Bank Lending to Emerging Market Countries." BIS Working Paper No.112, Bank for International Settlements. 
Kim, Don H., and Jonathan H. Wright. 2005. "An Arbitrage-Free Three-Factor Term Structure Model and the Recent Behavior of Long-Term Yields and Distant-Horizon Forward Rates."

Koepke, Robin. 2013. "Quantifying the Fed's Impact on Capital Flows to EMs." IIF Research Note.

Koepke, Robin. 2015. "What Drives Capital Flows to Emerging Markets? A Survey of the Empirical Literature." IIF Working Paper.

Koepke, Robin, and Saacha Mohammed. 2014. "EM Portfolio Flows Tracker 2.0 Methodology." IIF Research Note.

Krueger, Joel T., and Kenneth N. Kuttner. 1996. "The Fed Funds Futures Rate as a Predictor of Federal Reserve Policy." Journal of Futures Markets 16, no. 8: 865-879.

Kuttner, Kenneth N. 2001. "Monetary Policy Surprises and Interest Rates: Evidence from the Fed Funds Futures Market." Journal of Monetary Economics 47, no. 3: 523-544.

Lo Duca, Marco. 2012. "Modeling the Time Varying Determinants of Portfolio Flows to Emerging Markets." Working Paper Series 1468, European Central Bank.

Miao, Yanliang, and Malika Pant. 2012. "Coincident Indicators of Capital Flows." IMF Working Paper no. $12 / 55$.

Milesi-Ferretti, Gian-Maria, and Cédric Tille. 2011. "The Great Retrenchment: International Capital Flows during the Global Financial Crisis." Economic Policy 26, no. 66: 289-346.

Montiel, Peter, and Carmen M. Reinhart. 1999. "Do Capital Controls and Macroeconomic Policies Influence the Volume and Composition of Capital Flows? Evidence from the 1990s." Journal of International Money and Finance 18, no. 4 (1999): 619-635.

Rey, Hélène. 2013. "Dilemma not Trilemma: The Global Financial Cycle and Monetary Policy Independence." In: Jackson Hole Economic Symposium.

Rigobon, Roberto, and Brian Sack. 2004. "The Impact of Monetary Policy on Asset Prices." Journal of Monetary Economics 51, no. 8: 1553-1575.

Roley, V. Vance, and Gordon H. Sellon. 1995. "Monetary Policy Actions and Long-Term Interest Rates." Federal Reserve Bank of Kansas City Economic Quarterly 80, no. 4: 77-89.

Taylor, Mark P., and Lucio Sarno. 1977. "Capital Flows to Developing Countries: Long-and ShortTerm Determinants." The World Bank Economic Review 11, no. 3: 451-470.

World Bank. 1997. "Private Capital Flows to Developing Countries: the Road to Financial Integration." World Bank Policy Research Report, Oxford University Press, Oxford.

_. 2014. "Global Economic Prospects. Coping with Policy Normalization in High-Income Countries."

Woodford, Michael. 2012. "Methods of Policy Accommodation at the Interest-Rate Lower Bound." The Changing Policy Landscape: 2012 Jackson Hole Symposium. Federal Reserve Bank of Kansas City. 


\section{Annex 1: Charts of Main Regression Variables}

For variable descriptions, see Section 4, "Data and Empirical Strategy."

\section{Chart 1}

Flows to Emerging Market Dedicated Funds

$\$$ billion, monthly data

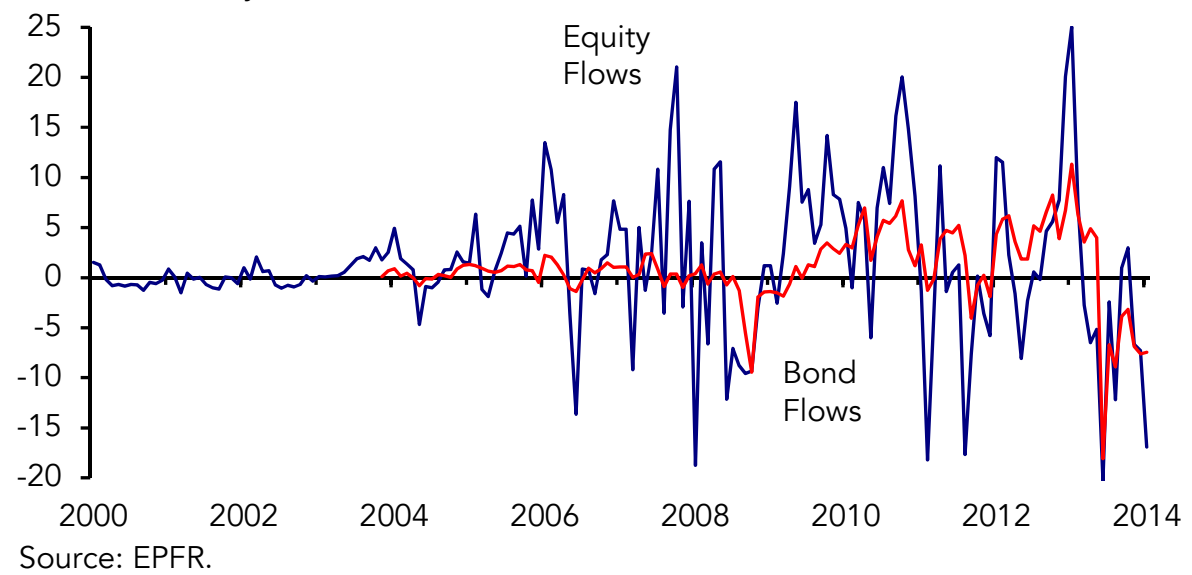

\section{Chart 2}

Non-Resident Portfolio Flows to Emerging Markets

$\$$ billion, monthly data

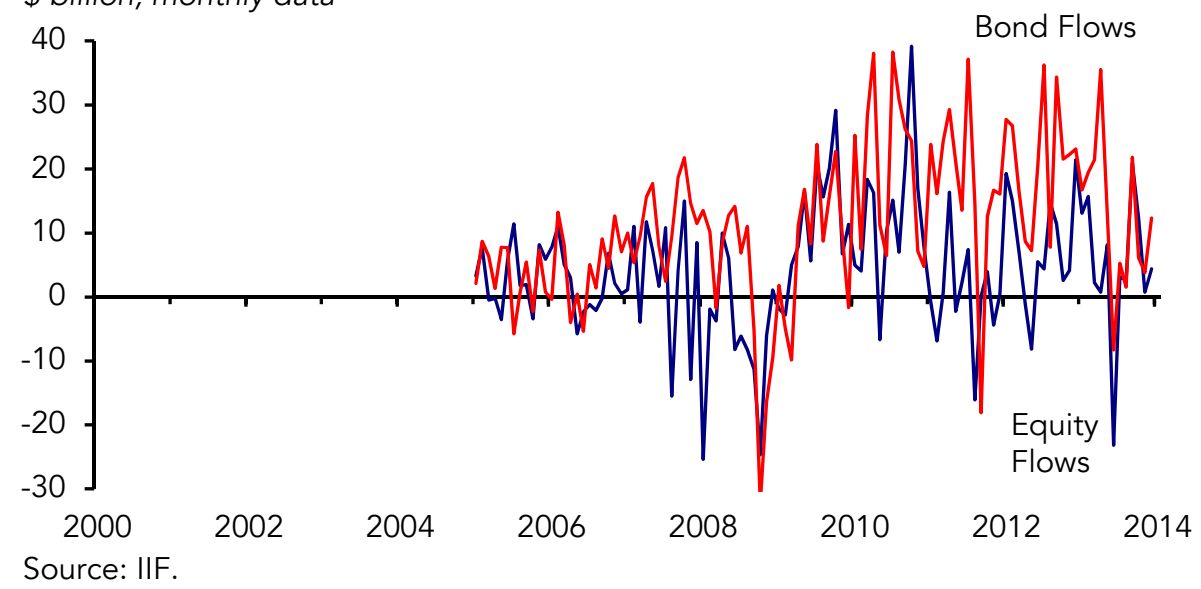




\section{Chart 3}

Market Expectations for the Federal Funds Rate in December 2015

percent per annum, based on fed funds futures contracts

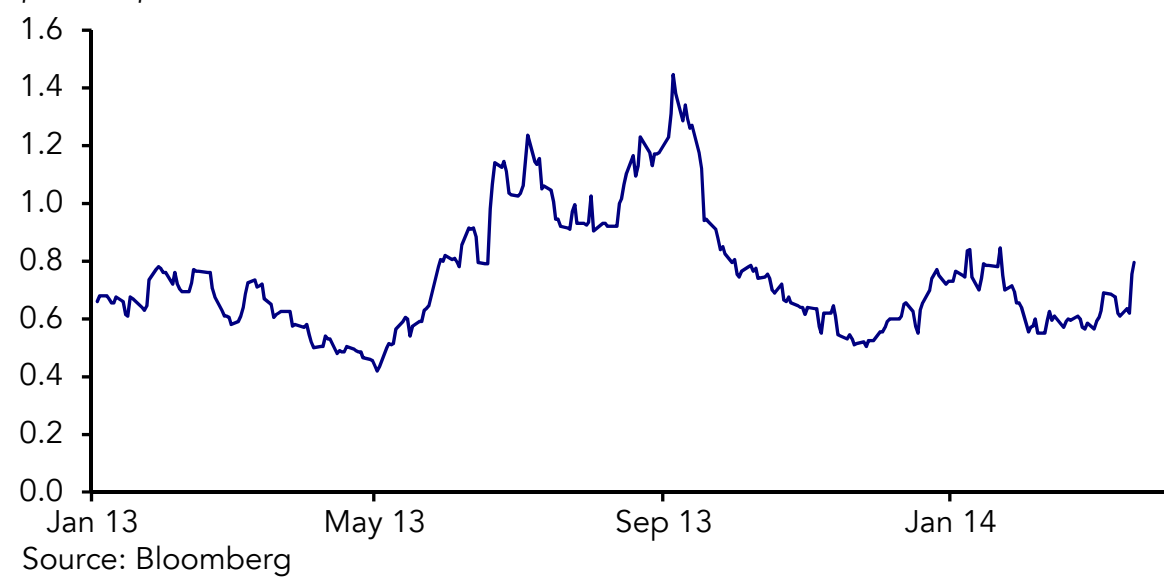

\section{Chart 4}

Monthly Change in Market Expectations for the Fed Funds Rate 3 Years Ahead percentage points, data prior to February 2011 are based on Eurodollar contracts

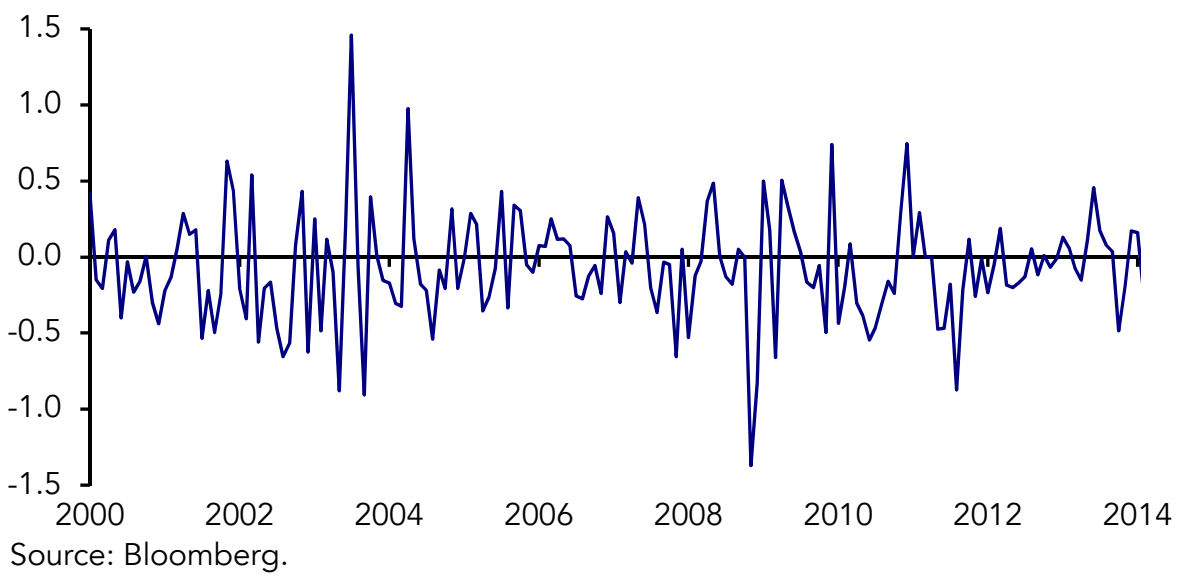

\section{Chart 5}

Cumulative Change in Market Expectations for the Fed Funds Rate 3 Years Ahead percentage points, data prior to February 2011 are based on Eurodollar contracts

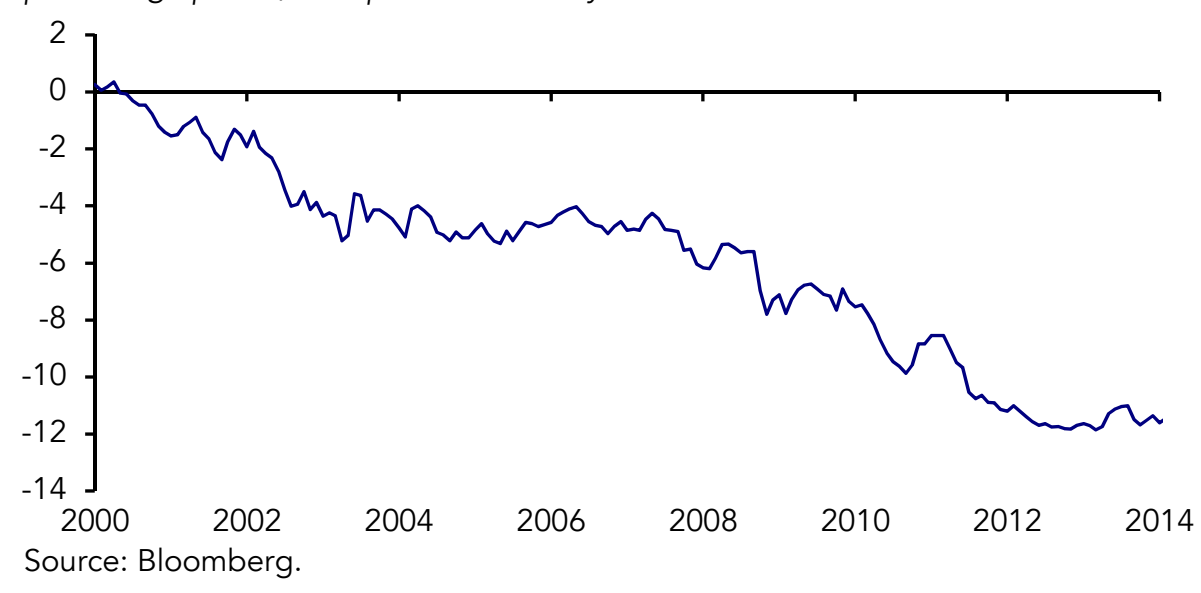



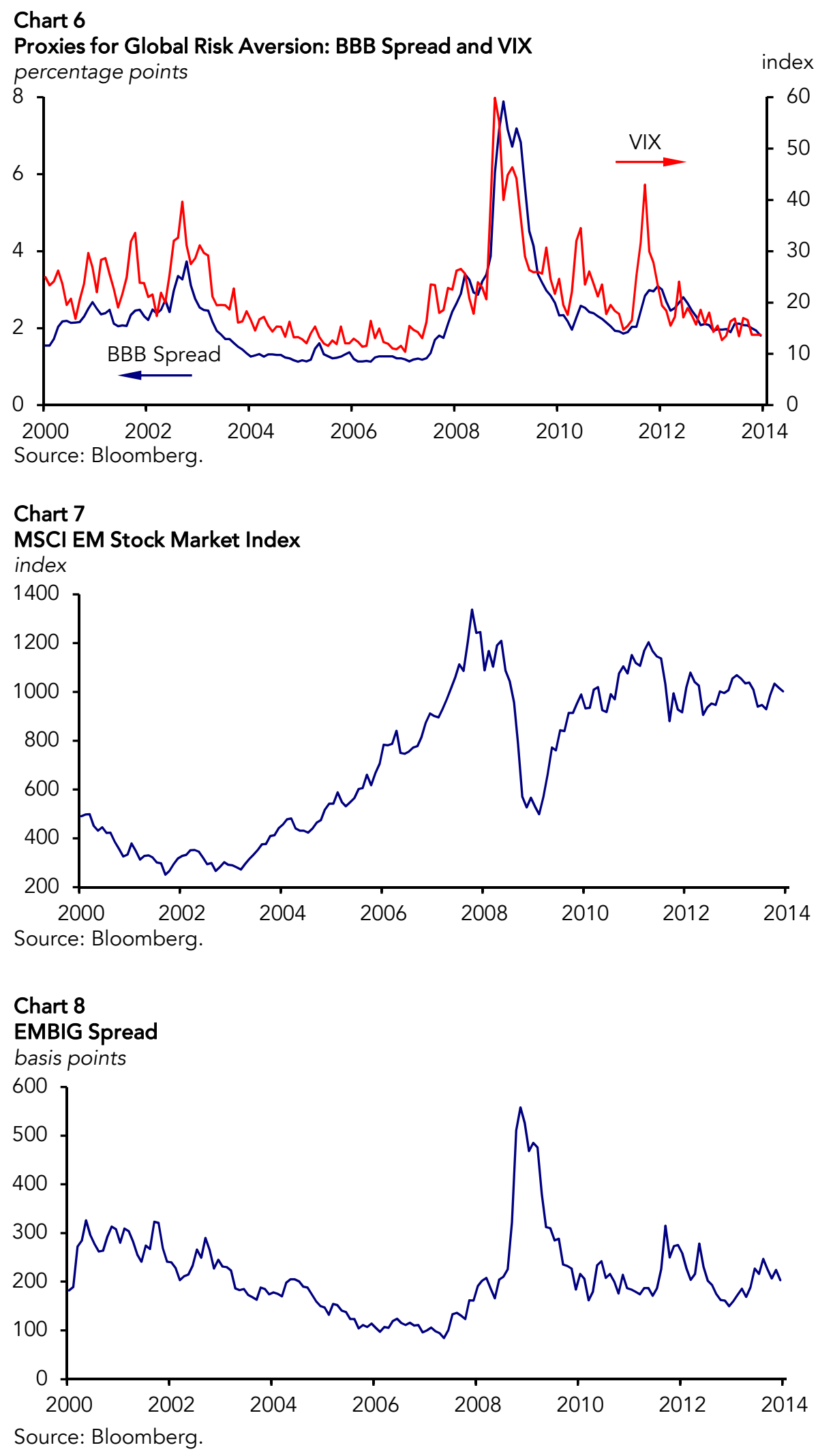


\section{Chart 9}

Emerging Market Economic Surprise Index

index, $0=$ breakeven

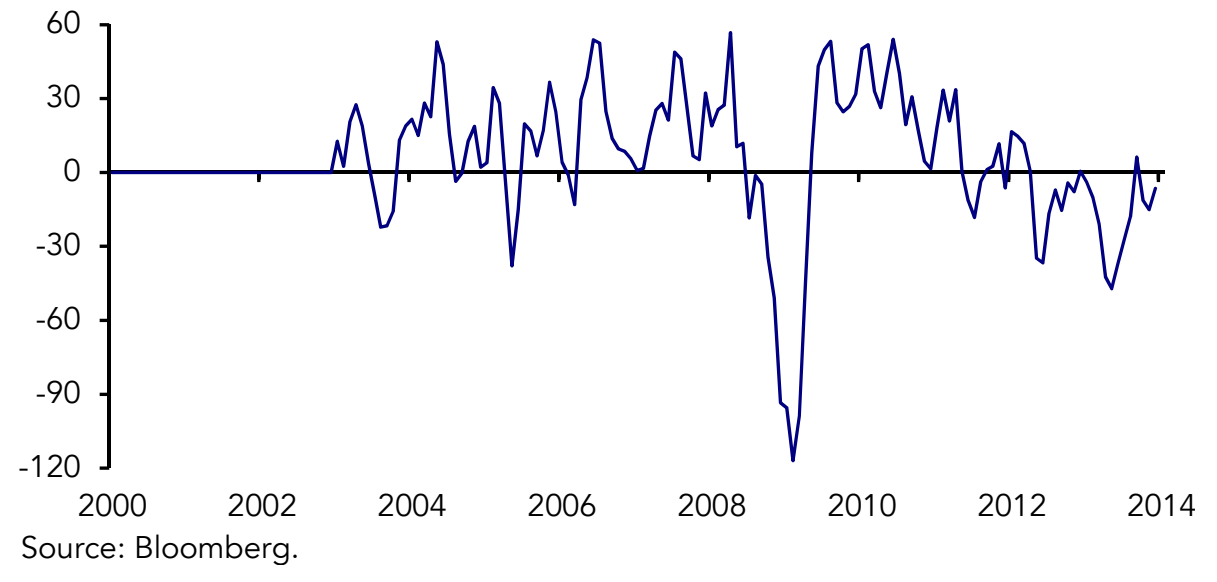

\section{Chart 10}

Federal Reserve: Total Assets

$\$$ billion

4000

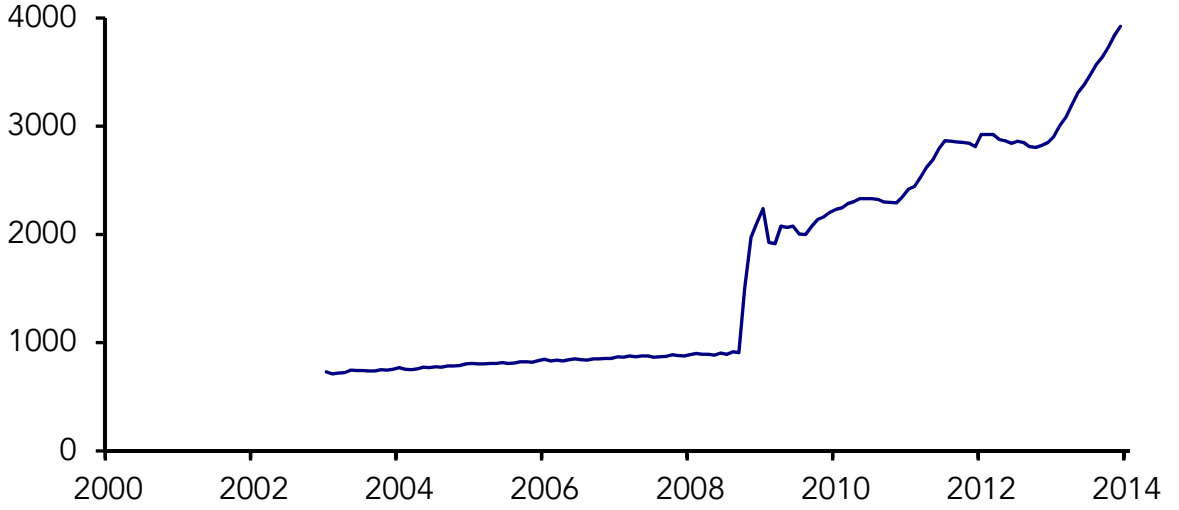

Source: Datastream.

\section{Chart 11}

Policy Interest Rate Differential between Emerging and Mature Economies percentage points

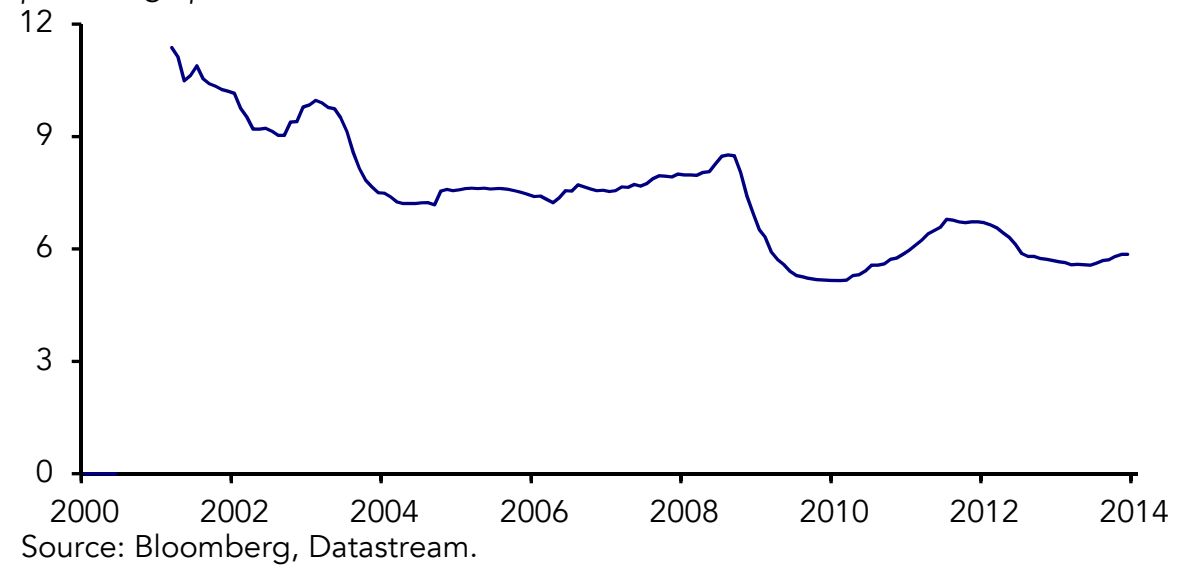




\section{Annex 2: Additional Estimation Results}

Notes: Asterisks denote significance at the 10\%,5\% and $1 \%$ level for 1, 2, and 3 asterisks, respectively. Standard errors are in parentheses. Models were estimated using monthly data for July 2002 to March 2007, to the extent that the needed data are available. Portfolio debt flows data are available from December 2003 onwards, resulting in a somewhat shorter sample period for regressions that include these flows. Functional forms are based on standard stationarity tests for all variables (Augmented Dickey-Fuller tests). The dependent variable is net flows to EMdedicated fixed income funds as reported by EPFR. Flows 1 is the lagged dependent variable. Monetary Policy Expectations refers to the change in the federal funds futures contract three years into the future. BBB Spread is the change in the yield difference on U.S. BBB-rated corporate bonds relative to U.S. Treasuries. MSCI EM is the percent change in the MSCI EM stock market index from the prior month. EMBIG Spread is the change from the prior month in the yield (in basis points) of the JPMorgan Emerging Markets Bond Index Global. For further details, see Section 4.

Table 4a: Estimation Results for Bond Fund Flows - Asymmetric Model (2010-2013)

\begin{tabular}{|c|c|c|c|c|}
\hline Flows $_{t-1}$ & $\begin{array}{l}0.674^{\star * \star} \\
(0.091)\end{array}$ & $\begin{array}{l}0.617^{\star * \star} \\
(0.098)\end{array}$ & $\begin{array}{l}0.675^{\star \star \star} \\
(0.092)\end{array}$ & $\begin{array}{l}0.733^{\star \star \star} \\
(0.094)\end{array}$ \\
\hline Tighter Monetary Policy Expectations & $\begin{array}{l}-10.397 \text { ***} \\
(3.058)\end{array}$ & $\begin{array}{l}-9.671 \text { ***} \\
(3.378)\end{array}$ & $\begin{array}{l}-10.165 \text { *** } \\
(3.098)\end{array}$ & $\begin{array}{l}-10.282 \text { *** } \\
(3.226)\end{array}$ \\
\hline Easier Monetary Policy Expectations & $\begin{array}{l}-4.793 \text { ** } \\
(2.012)\end{array}$ & $\begin{array}{l}-4.119 \text { * } \\
(2.320)\end{array}$ & $\begin{array}{l}-4.819 * * \\
(2.040)\end{array}$ & $\begin{array}{l}-4.553 * \star \\
(2.146)\end{array}$ \\
\hline BBB Spread & $\begin{array}{l}-9.936^{* \star \star} \\
(3.179)\end{array}$ & $\begin{array}{l}-13.211 * \star \star \\
(3.308)\end{array}$ & $\begin{array}{l}-9.996 * \star \star \\
(3.249)\end{array}$ & \\
\hline MSCI EM & $\begin{array}{l}0.284 * * \star \\
(0.089)\end{array}$ & & & $\begin{array}{l}0.287^{\star \star \star} \\
(0.101)\end{array}$ \\
\hline EM Economic Surprise Index & & $\begin{array}{r}0.020 \\
(0.022)\end{array}$ & & \\
\hline EMBIG Spread & & & $\begin{array}{l}-0.052^{\star \star \star} \\
(0.018)\end{array}$ & \\
\hline VIX & & & & $\begin{array}{l}-0.321 \text { ** } \\
(0.151)\end{array}$ \\
\hline Adjusted $R^{2}$ & 0.65 & 0.57 & 0.64 & 0.61 \\
\hline Number of Observations & 48 & 48 & 48 & 48 \\
\hline
\end{tabular}


Table 4b: Estimation Results for Portfolio Bond Flows - Asymmetric Model (2010-2013)

Constant

Tighter Monetary Policy Expectations

Easier Monetary Policy Expectations

BBB Spread

$\mathrm{MSCl} \mathrm{EM}$

EMBIG Spread

VIX

EM Economic Surprise Index
(1)

(3)

$12.891 * \star \star$

(1.506)

$12.848 * \star \star$

(1.372)

$-20.910 * \star \star$

(7.295)

$-20.843 * \star *$

(6.701)

$-1.932$

(5.877)

$-3.207$

(5.139)

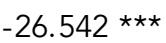

(6.502)

$-20.363 * * *$

(6.181)

$0.495 * * *$

(0.163)
(4)

13.801 ***

(1.445) -20.044 **

(7.496)

1.770

(5.338)

0.897

$(0.240) * \star \star$

0.005

(0.040)

$-0.091 * \star \star$

(0.032)

0.377

(0.295)

Adjusted $\mathrm{R}^{2}$

0.46

48

0.35

48

0.45

0.339541

Number of Observations

48

48 
Table 5a: Estimation Results for Equity Fund Flows - Asymmetric Model (2010-2013)

(1)

(2)

(3)

Flows $_{\mathrm{t}-1}$

$\begin{array}{ccc}0.526 * \star \star & 0.423 * \star \star & 0.54^{\star \star \star} \\ (0.110) & (0.131) & (0.093)\end{array}$

Tighter Monetary Policy Expectations

-10.649 *

$-7.844$

-11.578 *

(6.376)

(7.666)

(5.968)

Easier Monetary Policy Expectations

$-2.055$

1.465

$-4.430$

(3.980)

(4.980)

(3.774)

BBB Spread

$-4.504$

-15.442 **

(7.130)

(7.962)

$\mathrm{MSCl} \mathrm{EM}$

$0.880 * * *$

0.682 ***

(0.184)

$(0.184)$

EM Economic Surprise Index

$$
0.086 \text { * }
$$

(0.049)

$\mathrm{VIX}$

-0.72 **

(0.279)

\begin{tabular}{lrrr}
\hline Adjusted $R^{2}$ & 0.55 & 0.35 & 0.60 \\
Number of Observations & 48 & 48 & 48 \\
\hline
\end{tabular}


Table 5b: Estimation Results for Portfolio Equity Flows - Asymmetric Model (2010-2013)

(1)

Constant

Tighter Monetary Policy Expectations

Easier Monetary Policy Expectations

BBB Spread

$\mathrm{MSCl} \mathrm{EM}$

EMBIG Spread

VIX

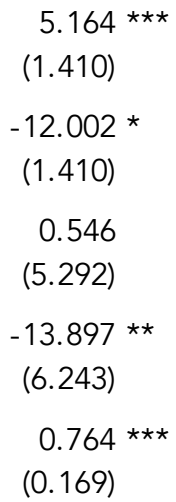

(2)

$6.058 * * \star$

(1.656)

$5.960 * \star *$

$-12.527$

(8.018)

7.265

(6.460)

-19.618 ***

(7.146)

0.764
$(0.169)$

EM Economic Surprise Index

0.082 *

(0.044)
(3)

1.130

$(0.231)$

$-10.853$

(7.222)

4.478

(5.144)

(3)

392)

130

(0.231) 
Estimation Results for the Pre-Crisis Period (July 2002 to March 2007)

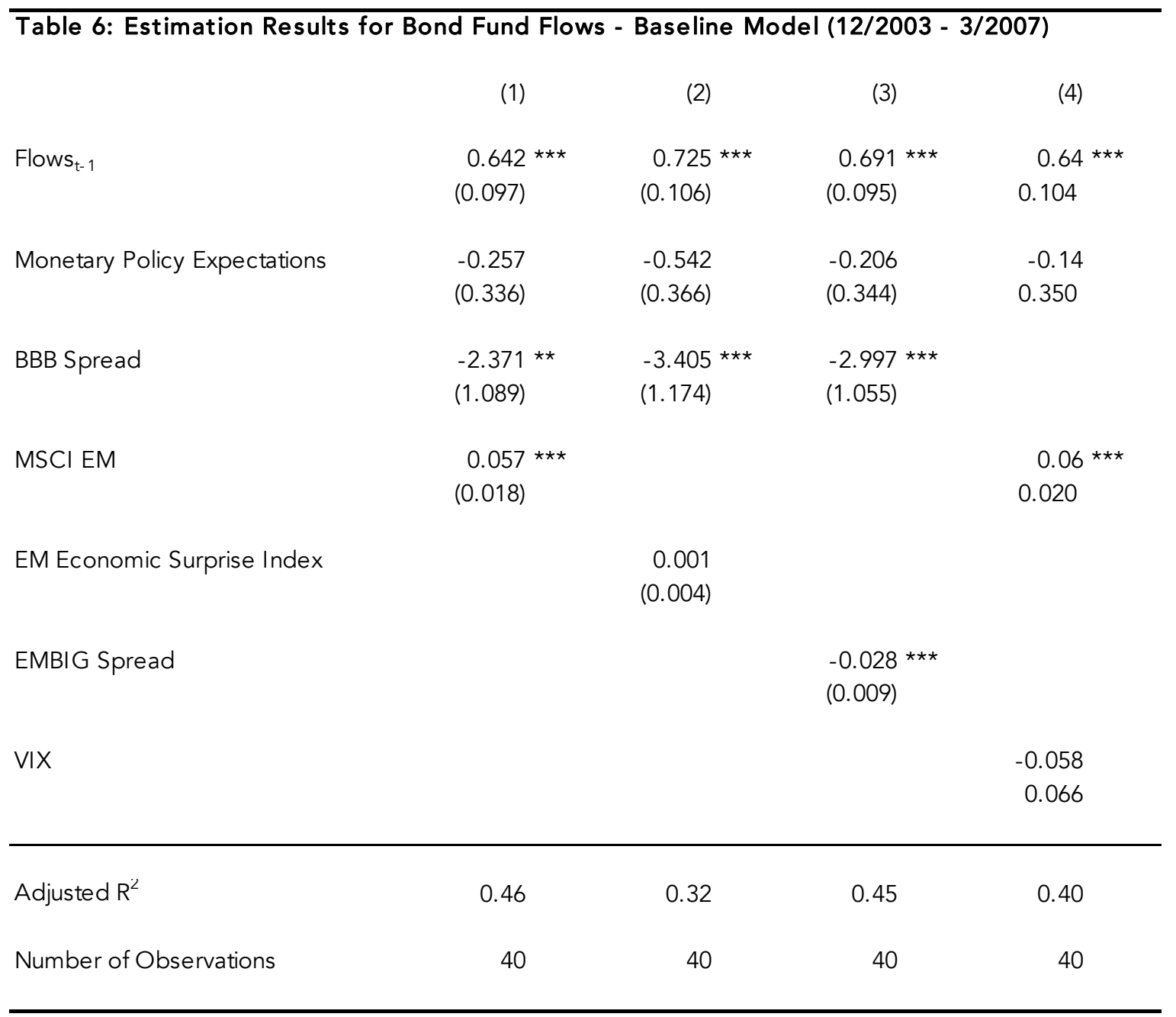


Table 7: Estimation Results for Equity Fund Flows - Baseline Model (7/2002 - 3/2007)

(2)

(3)

Flows $_{\mathrm{t}-1}$

$0.427^{\star \star \star}$

$0.427 * \star \star$

$0.45^{* \star *}$

(0.112)

(0.131)

0.115

Monetary Policy Expectations

$-0.218$

0.046

$-0.323$

(1.186)

(1.503)

1.212

BBB Spread

$-1.896$

$-12.923 * *$

(2.759)

(5.553)

MSCI EM

0.338 ***

(0.086)

$0.313^{* * *}$

0.101

EM Economic Surprise Index

$-0.011$

(0.025)

VIX

$-0.165$

0.236

Adjusted $R^{2}$

0.30

0.12

0.30

Number of Observations

57

51

57 


\begin{tabular}{|c|c|c|c|c|}
\hline & (1) & (2) & (3) & (4) \\
\hline Flows $_{t-1}$ & $\begin{array}{l}0.5677^{* * *} \\
(0.106)\end{array}$ & $\begin{array}{l}0.603 \text { *** } \\
(0.104)\end{array}$ & $\begin{array}{l}0.613^{* * *} \\
(0.117)\end{array}$ & $\begin{array}{l}0.572 \text { ***} \\
(0.115)\end{array}$ \\
\hline Tighter Monetary Policy Expectations & $\begin{array}{r}0.264 \\
(0.462)\end{array}$ & $\begin{array}{r}0.382 \\
(0.467)\end{array}$ & $\begin{array}{r}0.305 \\
(0.565)\end{array}$ & $\begin{array}{l}0.343 \\
0.496\end{array}$ \\
\hline Easier Monetary Policy Expectations & $\begin{array}{l}-0.881 \text { * } \\
(0.510)\end{array}$ & $\begin{array}{l}-0.894 \text { ** } \\
(0.508)\end{array}$ & $\begin{array}{l}-1.438 \text { ** } \\
(0.585)\end{array}$ & $\begin{array}{l}-0.704 \\
0.534\end{array}$ \\
\hline BBB Spread & $\begin{array}{l}-2.411 \text { ** } \\
(1.067)\end{array}$ & $\begin{array}{l}-2.989 * \star \star \\
(1.024)\end{array}$ & $\begin{array}{l}-3.287 * \star \star \\
(1.134)\end{array}$ & \\
\hline $\mathrm{MSCl} \mathrm{EM}$ & $\begin{array}{l}0.054 \text { *** } \\
(0.018)\end{array}$ & & & $\begin{array}{l}0.060 \text { *** } \\
0.020\end{array}$ \\
\hline EMBIG Spread & & $\begin{array}{l}-0.027 \text { ***} \\
(0.009)\end{array}$ & & \\
\hline EM Economic Surprise Index & & & $\begin{array}{l}-0.004 \\
(0.005)\end{array}$ & \\
\hline VIX & & & & $\begin{array}{r}-0.048 \\
0.065\end{array}$ \\
\hline Adjusted $\mathrm{R}^{2}$ & 0.48 & 0.49 & 0.36 & 0.42 \\
\hline Number of Observations & 40 & 40 & 40 & 40 \\
\hline
\end{tabular}


Table 9: Estimation Results for Equity Fund Flows - Asymmetric Model (7/2002 - 3/2007)

(2)

(3)

Flows $_{\mathrm{t}-1}$

$\begin{array}{lll}0.416^{* * *} & 0.408^{* * *} & 0.439^{\star * *} \\ 0.115 & 0.13^{*} & 0.118\end{array}$

Tighter Monetary Policy Expectations

$\begin{array}{lll}0.436 & 1.210 & 0.421\end{array}$

1.781

2.153

1.777

Easier Monetary Policy Expectations

$$
-0.777
$$

$-1.348$

$-0.978$

1.643

2.380

1.667

BBB Spread

$-1.723$

2.801

-11.542 *

5.869

$\mathrm{MSCl} \mathrm{EM}$

0.332 ***
0.088

$0.304 * \star \star$

0.103

EM Economic Surprise Index

$-0.016$

0.026

VIX

$-0.165$

0.238

Adjusted $\mathrm{R}^{2}$

0.29

0.11

0.29

Number of Observations

57

51

57 
Estimation Results for Federal Reserve Assets as Explanatory Variable

\begin{tabular}{|c|c|c|c|c|}
\hline & \multicolumn{2}{|c|}{ Debt } & \multicolumn{2}{|c|}{ Equity } \\
\hline & Baseline & Asymmetric & Baseline & Asymmetric \\
\hline Flows $_{t-1}$ & $\begin{array}{l}0.639 \text { *** } \\
(0.085)\end{array}$ & $\begin{array}{l}0.683 \text { *** } \\
(0.088)\end{array}$ & $\begin{array}{l}0.501 \text { *** } \\
(0.103)\end{array}$ & $\begin{array}{l}0.534 \text { *** } \\
(0.106)\end{array}$ \\
\hline Monetary Policy Expectations & $\begin{array}{l}-6.672 * * * \\
(1.644)\end{array}$ & & $\begin{array}{l}-4.894 \\
(3.267)\end{array}$ & \\
\hline Tighter Monetary Policy Expectations & & $\begin{array}{l}-10.615^{* * *} \\
(2.971)\end{array}$ & & $\begin{array}{c}-11.123 \text { * } \\
(6.165)\end{array}$ \\
\hline Easier Monetary Policy Expectations & & $\begin{array}{l}-4.934 \text { ** } \\
(1.955)\end{array}$ & & $\begin{array}{l}-2.441 \\
(3.851)\end{array}$ \\
\hline BBB Spread & $\begin{array}{l}-10.408 \text { *** } \\
(3.132)\end{array}$ & $\begin{array}{l}-10.046 \text { *** } \\
(3.087)\end{array}$ & $\begin{array}{l}-5.643 \\
(6.871)\end{array}$ & $\begin{array}{l}-4.641 \\
(6.890)\end{array}$ \\
\hline MSCI EM & $\begin{array}{l}0.242 \text { ** } \\
(0.091)\end{array}$ & $\begin{array}{l}0.246 \text { *** } \\
(0.089)\end{array}$ & $\begin{array}{l}0.795 \text { *** } \\
(0.184)\end{array}$ & $\begin{array}{l}0.796 \text { *** } \\
(0.183)\end{array}$ \\
\hline Fed Assets & $\begin{array}{c}0.022 \text { * } \\
(0.012)\end{array}$ & $\begin{array}{c}0.022 \text { * } \\
(0.012)\end{array}$ & $\begin{array}{c}0.049 \text { * } \\
(0.024)\end{array}$ & $\begin{array}{c}0.049 \text { * } \\
(0.024)\end{array}$ \\
\hline Adjusted $\mathrm{R}^{2}$ & 0.66 & 0.67 & 0.57 & 0.58 \\
\hline Number of Observations & 48 & 48 & 48 & 48 \\
\hline
\end{tabular}

Notes: This table shows regression results for the baseline and asymmetric models, augmented by the total assets held by the Federal Reserve as an additional explanatory variable. Based on standard stationarity tests, the variable is specified as the second difference, i.e. the change in the pace of asset accumulation. The variable is expressed in $\$$ billion and the data were obtained via Datastream. 
Estimation Results for Policy Interest Rate Differential as Explanatory Variable

\begin{tabular}{|c|c|c|c|c|}
\hline & \multicolumn{2}{|c|}{ Debt Flows } & \multicolumn{2}{|c|}{ Equity Flows } \\
\hline & $2010-2013$ & 2003-2007 & $2010-2013$ & 2002-2007 \\
\hline Policy Interest Rate Differential & $\begin{array}{l}-4.478 \\
(5.916)\end{array}$ & $\begin{array}{r}0.117 \\
(0.602)\end{array}$ & $\begin{array}{r}-0.695 \\
(14.657)\end{array}$ & $\begin{array}{l}-2.026 \\
(2.399)\end{array}$ \\
\hline Flows $_{t-1}$ & $\begin{array}{l}0.621 * \star \star \\
(0.089)\end{array}$ & $\begin{array}{l}0.652 \text { *** } \\
(0.111)\end{array}$ & $\begin{array}{l}0.391 \text { *** } \\
(0.127)\end{array}$ & $\begin{array}{l}0.389 \text { *** } \\
(0.118)\end{array}$ \\
\hline Monetary Policy Expectations & $\begin{array}{l}-6.716 * * * \\
(1.717)\end{array}$ & $\begin{array}{l}-0.261 \\
(0.341)\end{array}$ & & \\
\hline BBB Spread & $\begin{array}{l}-10.387 \text { *** } \\
(3.235)\end{array}$ & $\begin{array}{l}-2.387 * \star \\
(1.107)\end{array}$ & $\begin{array}{c}-15.831 \text { ** } \\
(7.486)\end{array}$ & $\begin{array}{l}-2.284 \\
(2.774)\end{array}$ \\
\hline $\mathrm{MSCI} \mathrm{EM}$ & $\begin{array}{l}0.287^{\star \star \star *} \\
(0.092)\end{array}$ & $\begin{array}{l}0.058 \text { *** } \\
(0.019)\end{array}$ & & $\begin{array}{l}0.313^{* \star \star} \\
(0.090)\end{array}$ \\
\hline EM Economic Surprise Index & & & $\begin{array}{l}0.088 \text { * } \\
(0.049)\end{array}$ & \\
\hline Adjusted $\mathrm{R}^{2}$ & 0.63 & 0.45 & 0.35 & 0.30 \\
\hline Number of Observations & 48 & 40 & 48 & 57 \\
\hline
\end{tabular}

Notes: This table shows regression results for the core baseline models, augmented by the policy interest rate differential between emerging and advanced economies as an additional explanatory variable. The policy interest rate differential is calculated as a GDP-weighted average of individual EM policy rates, less the federal funds target rate (see Section 4). It is expressed in percentage points. The estimated coefficient on this variable is not statistically significantly different from zero in any of the above specifications, suggesting that this variable was not among the key drivers of portfolio flows during the sample periods. 
Estimation Results for Portfolio flows by Institutional vs. Retail Investors

\begin{tabular}{|c|c|c|c|c|}
\hline & \multicolumn{2}{|c|}{ Debt } & \multicolumn{2}{|c|}{ Equity } \\
\hline & Institutional & Retail & Institutional & Retail \\
\hline Flows $_{t-1}$ & $\begin{array}{l}0.574 \text { *** } \\
(0.095)\end{array}$ & $\begin{array}{l}0.696 \text { *** } \\
(0.086)\end{array}$ & $\begin{array}{l}0.555 \text { *** } \\
(0.098)\end{array}$ & $\begin{array}{l}0.5433^{\text {***}} \\
(0.115)\end{array}$ \\
\hline Monetary Policy Expectations & $\begin{array}{l}-3.524 \text { *** } \\
(0.940)\end{array}$ & $\begin{array}{l}-3.072 \text { *** } \\
(0.903)\end{array}$ & $\begin{array}{l}-4.810 \text { ** } \\
(2.271)\end{array}$ & $\begin{array}{r}0.514 \\
(1.589)\end{array}$ \\
\hline BBB Spread & $\begin{array}{l}-5.291 \\
(1.772)\end{array}$ & $\begin{array}{l}-4.987^{\star \star \star} \\
(1.740)\end{array}$ & $\begin{array}{l}-2.552 \\
(4.669)\end{array}$ & $\begin{array}{l}-1.373 \\
(3.237)\end{array}$ \\
\hline $\mathrm{MSCI} \mathrm{EM}$ & $\begin{array}{l}0.148 * * * \\
(0.050)\end{array}$ & $\begin{array}{l}0.128 \text { ** } \\
(0.049)\end{array}$ & $\begin{array}{l}0.607 * * * \\
(0.122)\end{array}$ & $\begin{array}{l}0.278 \text { *** } \\
(0.088)\end{array}$ \\
\hline Adjusted $\mathrm{R}^{2}$ & 0.46 & 0.68 & 0.52 & 0.38 \\
\hline Number of Observations & 48 & 48 & 48 & 48 \\
\hline
\end{tabular}

Notes: This table shows regression results for the core baseline models, using EPFR fund flows by type of ultimate investor. Specifically, total EPFR fund flows are broken into two components, institutional investors and retail investors. 


\begin{tabular}{|c|c|c|c|c|}
\hline & Deb & & Equit & \\
\hline & Institutional & Retail & Institutional & Retail \\
\hline Flows $_{t-1}$ & $\begin{array}{l}0.587 \star \star \star \star \\
(0.108)\end{array}$ & $\begin{array}{l}0.725^{\star \star \star} \\
(0.083)\end{array}$ & $\begin{array}{l}0.567 * \star \star \\
(0.108)\end{array}$ & $\begin{array}{l}0.534 \text { *** } \\
(0.110)\end{array}$ \\
\hline Tighter Monetary Policy Expectations & $\begin{array}{l}-3.921 \star \star \\
(1.755)\end{array}$ & $\begin{array}{l}-6.196 * \star \star \\
-1.598\end{array}$ & $\begin{array}{l}-5.853 \\
(4.370)\end{array}$ & $\begin{array}{l}-5.041 \star \\
-2.857\end{array}$ \\
\hline Easier Monetary Policy Expectations & $\begin{array}{l}-3.323 * \star \star \\
(1.207)\end{array}$ & $\begin{array}{l}-1.850 \text { * } \\
(1.009)\end{array}$ & $\begin{array}{l}-4.349 \\
(2.821)\end{array}$ & $\begin{array}{r}2.561 \\
(1.760)\end{array}$ \\
\hline BBB Spread & $\begin{array}{l}-5.234^{\star \star \star} \\
(1.803)\end{array}$ & $\begin{array}{l}-4.848^{\star \star \star} \\
(1.661)\end{array}$ & $\begin{array}{l}-2.312 \\
(4.795)\end{array}$ & $\begin{array}{l}-1.359 \\
(3.091)\end{array}$ \\
\hline $\mathrm{MSCI} \mathrm{EM}$ & $\begin{array}{l}0.149 * \star \star \\
(0.051)\end{array}$ & $\begin{array}{l}0.127^{\star \star \star} \\
(0.047)\end{array}$ & $\begin{array}{l}0.608^{\star \star \star} \\
(0.124)\end{array}$ & $\begin{array}{l}0.271 \text { *** } \\
(0.084)\end{array}$ \\
\hline Adjusted $\mathrm{R}^{2}$ & 0.45 & 0.71 & 0.51 & 0.43 \\
\hline Number of Observations & 48 & 48 & 48 & 48 \\
\hline
\end{tabular}

Notes: This table shows regression results for the core baseline models, using EPFR fund flows by type of ultimate investor. Specifically, total EPFR fund flows are broken into two components, institutional investors and retail investors. 
Additional Estimation Results for Selected Variables (See Section 6, Robustness Checks)

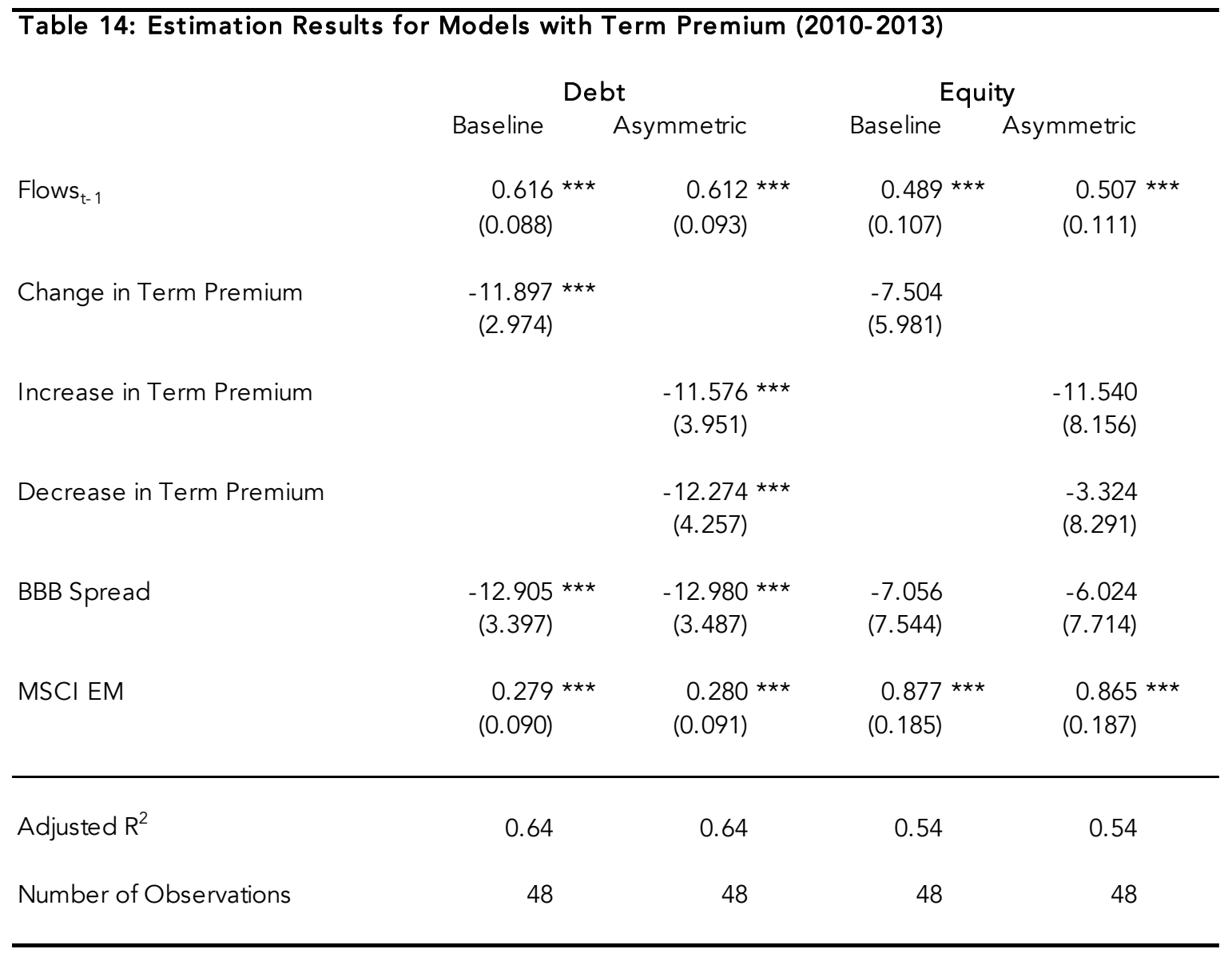

Notes: This table shows regression results for the baseline and asymmetric models, using changes in the term premium as the main push variable of interest, rather than changes in federal funds rate expectations. Term premium estimates were obtained based on Kim and Wright (2005) from the $\begin{array}{lccl}\text { following Federal } & \text { Reserve } & \text { web } & \text { page: } \\ \text { http://www.federalreserve.gov/pubs/feds/2005/200533/200533abs.html. Accessed May 7, } 2014 .\end{array}$ 


\begin{tabular}{|c|c|c|c|c|}
\hline & \multicolumn{2}{|c|}{ Debt } & \multicolumn{2}{|c|}{ Equity } \\
\hline & Baseline & Asymmetric & Baseline & Asymmetric \\
\hline Flows $_{t-1}$ & $\begin{array}{l}0.680 \text { *** } \\
(0.090)\end{array}$ & $\begin{array}{l}0.661 \text { *** } \\
(0.098)\end{array}$ & $\begin{array}{l}0.513 \text { *** } \\
(0.107)\end{array}$ & $\begin{array}{l}0.507^{* \star *} \\
(0.110)\end{array}$ \\
\hline Change in Slope of US Yield Curve & $\begin{array}{l}-9.362 * * * \\
(3.084)\end{array}$ & & $\begin{array}{l}-4.706 \\
(6.039)\end{array}$ & \\
\hline Increase in Slope of US Yield Curve & & $\begin{array}{l}-7.928 \text { * } \\
-4.158\end{array}$ & & $\begin{array}{l}-3.049 \\
(8.216)\end{array}$ \\
\hline Decrease in Slope of US Yield Curve & & $\begin{array}{c}-11.043 \text { ** } \\
(4.488)\end{array}$ & & $\begin{array}{l}-6.414 \\
(8.331)\end{array}$ \\
\hline BBB Spread & $\begin{array}{l}-10.915 \text { *** } \\
(3.495)\end{array}$ & $\begin{array}{l}-11.195 * * * \\
(3.565)\end{array}$ & $\begin{array}{l}-4.934 \\
(7.308)\end{array}$ & $\begin{array}{l}-5.239 \\
(7.454)\end{array}$ \\
\hline $\mathrm{MSCl} \mathrm{EM}$ & $\begin{array}{l}0.335 \text { *** } \\
(0.098)\end{array}$ & $\begin{array}{l}0.342 \text { *** } \\
(0.100)\end{array}$ & $\begin{array}{l}0.901 \text { *** } \\
(0.193)\end{array}$ & $\begin{array}{l}0.9111^{* * *} \\
(0.198)\end{array}$ \\
\hline Adjusted $R^{2}$ & 0.60 & 0.59 & 0.53 & 0.52 \\
\hline Number of Observations & 48 & 48 & 48 & 48 \\
\hline
\end{tabular}

Notes: This table shows regression results for the baseline and asymmetric models, using changes in the slope of the U.S. yield curve as the main push variable of interest, rather than changes in federal funds rate expectations. The slope in the yield curve is calculated as the average yield on 10-year Treasuries for the month minus the average yield on 2-year Treasuries for the month. The data were obtained from Bloomberg. 


\begin{tabular}{|c|c|c|c|c|}
\hline \multicolumn{3}{|c|}{$\begin{array}{r}\text { Table 16: Estimation Results for Models with 3-Y } \\
\text { Debt }\end{array}$} & \multicolumn{2}{|c|}{ Equity } \\
\hline & & Asymmetric & Baseline & Asymmetric \\
\hline Flows $_{t-1}$ & $\begin{array}{l}0.682 \text { *** } \\
(0.078)\end{array}$ & $\begin{array}{l}0.720 \text { *** } \\
(0.083)\end{array}$ & $\begin{array}{l}0.480 \text { *** } \\
(0.105)\end{array}$ & $\begin{array}{l}0.502 \text { ***} \\
(0.108)\end{array}$ \\
\hline Change in 3-Year Treasury Yields & $\begin{array}{l}-13.789 * * * \\
(2.758)\end{array}$ & & $\begin{array}{c}-11.225 \text { * } \\
(6.062)\end{array}$ & \\
\hline Increase in 3-Year Treasury Yields & & $\begin{array}{l}-17.819 \text { *** } \\
-4.089\end{array}$ & & $\begin{array}{c}-16.866 \text { * } \\
(8.860)\end{array}$ \\
\hline Decrease in 3-Year Treasury Yields & & $\begin{array}{c}-10.4777^{\star \star \star} \\
(3.704)\end{array}$ & & $\begin{array}{l}-6.561 \\
(8.084)\end{array}$ \\
\hline BBB Spread & $\begin{array}{l}-12.047 * * * \\
(3.037)\end{array}$ & $\begin{array}{l}-11.920 * * * \\
(3.012)\end{array}$ & $\begin{array}{l}-7.769 \\
(7.200)\end{array}$ & $\begin{array}{l}-7.296 \\
(7.240)\end{array}$ \\
\hline MSCI EM & $\begin{array}{l}0.263^{* * *} \\
(0.084)\end{array}$ & $\begin{array}{l}0.262 \text { ***} \\
(0.083)\end{array}$ & $\begin{array}{l}0.856 \text { ***} \\
(0.181)\end{array}$ & $\begin{array}{l}0.849 \text { *** } \\
(0.182)\end{array}$ \\
\hline Adjusted $\mathrm{R}^{2}$ & 0.69 & 0.70 & 0.56 & 0.56 \\
\hline Number of Observations & 48 & 48 & 48 & 48 \\
\hline
\end{tabular}

Notes: This table shows regression results for the baseline and asymmetric models, using changes in 3 -year Treasury yields as the main push variable of interest, rather than changes in federal funds rate expectations. The data were obtained from Bloomberg. 


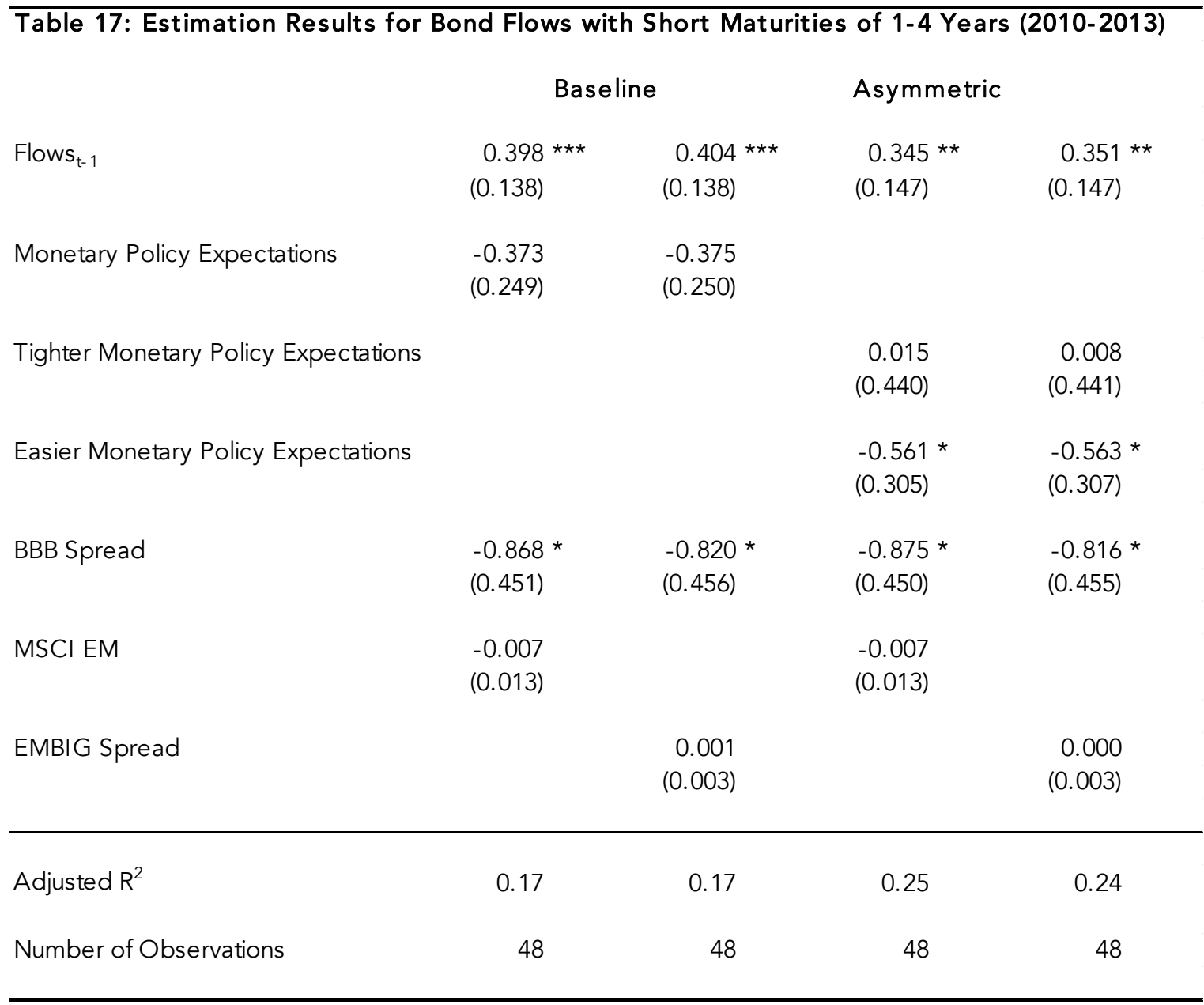

Notes: This table shows regression results for bond flows related to purchases and sales of bonds with short maturities of up to 4 years. Bond flows data by maturities were kindly provided by EPFR and are based on reported transactions from funds that only invest in a particular range of maturities (short term, intermediate term, and long term). In practice, the assets under management (AUM) for the intermediate and long-term range are too small ( $<\$ 1$ billion) to draw any reliable inferences, while for short-dated bonds, AUM of $\$ 6$ to $\$ 32$ billion in 2010-2013 may be sufficiently large to draw such inferences. 